\title{
Market integration, country institutions and IPO underpricing
}

Article

Accepted Version

Creative Commons: Attribution-Noncommercial-No Derivative Works 4.0

Marcato, G., Milcheva, S. and Zheng, C. (2018) Market integration, country institutions and IPO underpricing. Journal of Corporate Finance, 53. pp. 87-105. ISSN 0929-1199 doi: https://doi.org/10.1016/j.jcorpfin.2018.10.002 Available at https://centaur.reading.ac.uk/79673/

It is advisable to refer to the publisher's version if you intend to cite from the work. See Guidance on citing.

To link to this article DOI: http://dx.doi.org/10.1016/j.jcorpfin.2018.10.002

Publisher: Elsevier

All outputs in CentAUR are protected by Intellectual Property Rights law, including copyright law. Copyright and IPR is retained by the creators or other copyright holders. Terms and conditions for use of this material are defined in the End User Agreement.

\section{www.reading.ac.uk/centaur}

\section{CentAUR}

Central Archive at the University of Reading

Reading's research outputs online 


\title{
Market Integration, Country Institutions and IPO Underpricing
}

\author{
Gianluca Marcato ${ }^{1}$ \\ University of Reading United Kingdom \\ Stanimira Milcheva ${ }^{2}$ \\ University College London United Kingdom \\ Chen Zheng ${ }^{3^{\#}}$ \\ University of Reading United Kingdom
}

${ }^{1}$ Email: g.marcato@henley.reading.ac.uk. University of Reading, Reading, RG6 6AH, UK. Tel: +44 1183788178 .

22Email: s.milcheva@ucl.ac.uk. University College London, London, WC1E 6BT, UK. Tel: Tel: +44 2076795946 .

${ }^{3}\left[{ }^{\#}\right.$ Corresponding author] Email: chen.zheng@henley.reading.ac.uk. University of Reading, Reading, RG6 6AH, UK. Tel: +44 1183788878. 


\title{
Market Integration, Country Institutions and IPO Underpricing
}

\begin{abstract}
We extend the IPO literature analysing the role of financial market integration in the development of IPO markets and the pricing of newly listed stocks. Using a hierarchical linear model, we show that differences in underpricing between markets with high and low financial integration levels are economically significant and may explain the choice of location in the listing process. Firstly, market integration negatively affects the level of IPO underpricing by increasing the importance and efficiency of the financial intermediation process via tradable securities. Secondly, the presence of a deeper market integration has a moderation effect, which weakens the explanatory power of country institutions in the cross-country variation of IPO underpricing. Finally, we suggest a hierarchical structure be assumed for the modelling of cross-country IPO studies with heterogeneous country characteristics. Our results are robust to alternative measures of financial integration and several model specifications.
\end{abstract}

Key Words: Financial Market Integration, IPO Underpricing, Country Institutions, Hierarchical Linear Modelling, Foreign IPOs.

JEL Code: G2, G3, F3 


\section{Introduction}

Even if the cross-country variation of IPO underpricing is a well-known phenomenon (Loughran et al., 1994, updated in 2015), the institutional settings of a country (hereafter country institutions) have become less important for the decision of going public domestically or abroad due to the increased integration of financial markets (Doidge et al., 2013). This is in line with the widely-accepted argument in the law and finance literature that the influence of country institutions in corporate decision-making decreases as increasing financial globalization allows firms to choose institutions of other countries.

A growing stream of literature examines the impact of country institutions, such as legal frameworks, on the significant cross-country variation in IPO underpricing, after controlling for firm- and issuing-specific factors (Banerjee et al., 2011, Engelen and Essen, 2010, Hopp and Dreher, 2013). More recently, Doidge et al. (2013) and Caglio et al. (2016) show how financial integration positively supports the development of IPO markets (number and size of listings) and moderates the effect of country institutions on IPO decisions. In our paper, we combine and extend this literature by assessing how the increasing exposure of local markets to global factors reduces IPO underpricing and weakens the impact that country institutions have on the cross-country variation in IPO underpricing.

To our knowledge, this paper represents the first attempt to link IPO underpricing with financial market integration and the main contribution to the literature is threefold. Firstly, we argue that market integration directly increases both the importance and efficiency of its financial intermediation process via tradable securities (including IPO underwriting), which in turn negatively impacts the level of IPO underpricing. The inverse relationship between the efficiency of financial intermediation and the level of underpricing is extensively supported by empirical evidence following the information extraction theory by Benveniste and Spindt (1989). ${ }^{1}$ During the financial integration process, the focus of the banking business shifts away from the traditional depositary business to a one more heavily relying on wholesale markets and financial intermediation by using tradable securities (e.g. providing IPO and SEO underwriting services). An investment bank's market share of underwriting deals is affected by the efficiency of its previous underwriting performance, measured by the level of underpricing (Beaty and Ritter, 1986). Meanwhile, the market integration process

\footnotetext{
${ }^{1}$ See also (Carter and Manaster, 1990, Carter et al., 1998, Chemmanur and Fulghieri, 1994, Nanda and Youngkeol, 1997, Tinic, 1988).
} 
reduces the competitive advantage of domestic banks through the presence of an increased number of foreign banks in domestic markets and increased opportunities to access finance in foreign markets. To respond to the growing role of financial intermediation, the overall quality of financial services is improved. This may occur through a spillover effect, where less competitive domestic players try to learn from foreign banks and institutions with better financial systems. Consequently, the efficiency of the financial intermediation process in the home country should improve due to its increasing level of integration with the global market. In line with this expectation, we find that market integration reduces IPO underpricing.

Secondly, the law and finance literature demonstrates that a growing globalization weakens the role of country institutions on corporate finance activities (Doidge et al., 2007, Doidge et al., 2013, Kho et al., 2009, Stulz, 1999, Stulz, 2009). Following this evidence, we argue that financial market integration also works as a moderation effect weakening the explanatory power of country institutions in the cross-country variation of IPO underpricing. Particularly, market integration allows companies to access finance in foreign markets and to borrow from foreign institutions, reducing the cost of funding. In fact, we show that the boundaries between capital markets in different countries fade away and the impact of country institutions on the cross-country IPO underpricing is weakened. These results also help us to understand the regional conditions for foreign IPO investment opportunities. They provide issuers and underwriters with an insight into the economic effects of country institutions on IPO underpricing in a wider context of financial integration. More widely, our findings indicate that the process of financial market integration with the global market improves the efficiency on primary markets and reduces the cost of equity internationally by driving the convergence of institutional quality across countries.

Finally, from a methodological standpoint, we apply hierarchical linear modelling to a large dataset that has a clustering structure, using a mixed-effects model. Moving away from a simple OLS estimation used in previous international studies, we are able to test the country-level effects and correct for the country clustering structure at the same time, which cannot be realized by a fixed effect model. Our results are also confirmed by propensity score matching, which reveals a 10\% reduction of IPO underpricing when markets are financially integrated.

The paper is organised as follows: the next section summarises the literature review and develops the research hypotheses. Section 3 presents the data collection process and 
estimation models. Sections 4 and 5 discuss main results and robustness tests, while section 6 concludes the paper.

\section{Literature review and hypotheses development}

The literature on IPO underpricing is substantial and previous studies explain this phenomenon focusing on pre-market activities following either an information-asymmetrybased theory, or an aftermarket demand-driven behavioural argument. ${ }^{2}$ The first stream generally argues that underpricing is a consequence of the information asymmetry existing between the agents involved in an IPO event. The first systematic information asymmetry model by Rock (1986) argues that some investors have better information about the IPO valuation than the issuers and underwriters. Underpricing is used as a compensation for investors with information disadvantages who are otherwise reluctant to participate in IPOs. Beaty and Ritter (1986) show that uninformed investors are discouraged by the "winner's curse" risk and issuers use underpricing to attract investors who believe that shares are only available because they are mispriced or unwanted. Finally, signalling models present underpricing as a strategy adopted by issuers to signal the company's quality. In this set-up, only well-performing companies are able to afford the initial cost of underpricing which can be recovered in the subsequent season equity offerings (Allen and Faulhaber, 1989, Grinblatt and Hwang, 1989, Welch, 1989).

On the other hand, behavioural arguments focus on the IPO issuance process. Brailsford et al. (2004) document how general market conditions and investors' sentiment affect IPO volumes and underpricing. The prospect theory by Loughran and Ritter (2002) shows that the value of investors' holdings increases substantially after the first day of trading compared to the expected valuation based on the initial file range of the offer price. Compared with the value gain, the diluted wealth (or value loss) due to underpricing seems negligible and therefore, issuers accept a certain level of underpricing. ${ }^{3}$

Finally, the presence of different institutions in the IPO process might also impact underpricing such as auditor's quality (Beaty, 1989), ${ }^{4}$ status of venture capital-backing (Barry

\footnotetext{
${ }^{2}$ For a very detailed review on the IPO literature, please refer to Ritter and Welch (2002).

3 See, for example Derrien (2005), Ljungqvist et al. (2006) and Reber and Vencappa (2016) for more behavioural arguments on IPO underpricing.

${ }^{4}$ Hong et al. (2014) also find that the adoption of mandatory International Financial Reporting Standards has a negative impact on the level of IPO underpricing.
} 
et al., 1990, Gompers, 1996, Lerner, 1994), ownership structure pre- and post-IPO (Brennan and Franks, 1997) and the role of underwriters (Beaty and Ritter, 1986, Carter and Manaster, 1990, Carter et al., 1998, Chemmanur and Fulghieri, 1994, Ellis et al., 2000, Nanda and Youngkeol, 1997, Tinic, 1988, Boeh and Dunbar, 2016). Moreover, although the focus in previous literature has been on firm- and issue-specific variables, more recent international studies show that country institutions are also important to explain the cross-country variation in IPO underpricing (Banerjee et al., 2011, Engelen and Essen, 2010, Hopp and Dreher, 2013). We extend the literature by focussing on the roles of financial market integration in the IPO underpricing anomaly. The next two sections describe our research hypotheses.

\section{Direct effect of financial market integration on IPO underpricing}

IPOs represent complex financial deals where company information is not fully disclosed and the involvement of several independent institutions (i.e. issuer, investors and underwriters) makes the financial intermediation process highly relevant to understand the pricing dynamics. The information extraction theory by Benveniste and Spindt (1989) represents the most empirically supported theoretical setting. The authors argue that the bookbuilding process of an IPO represents the information extraction process during which the underwriters retrieve useful information from informed investors to set an appropriate offering price. Therefore, the efficiency of this information extraction process is critical to the level of underpricing. On one hand, acting as information producers, underwriters set standards to obtain an issuing company's valuation; on the other hand, underwriters try to extract useful information from informed investors and compensate them with a certain level of underpricing. However, as both actions are unobservable, issuers choose underwriters according to their reputation based on past performance (i.e. success) and underpricing. When underwriters either overprice or heavily underprice, their subsequent market share decreases (Beaty and Ritter, 1986, Carter and Manaster, 1990, Carter et al., 1998, Chemmanur and Fulghieri, 1994, Nanda and Youngkeol, 1997, Tinic, 1988, Sherman, 2005). Hence, investment banks have incentives to improve the efficiency of the financial intermediation process to set an appropriate offer price.

In particular, financial market integration impacts on the underwriting process because a market's financial exposure to global factors can "increase the depth and breadth of domestic financial markets and lead to an increase in the degree of efficiency of the financial intermediation process" (Agénor, 2003). In fact, market integration significantly 
enhances the competitiveness of the banking system through different mechanisms. Firstly, it increases the competition for domestic banks by raising the number of foreign banks operating in local markets (Caprio and Honohan, 1999) and allowing companies to access more affordable financing opportunities in foreign markets. As far as IPOs are concerned, financial integration reduces the costs and improves the likelihood of domestic companies going public abroad to access better institutional settings. Financial integration is found to increase the number of global IPOs - Doidge et al. (2013) - and to precipitate the shift of banks from the traditional loans and depository business, to financial intermediation based on securities - Hausler (2002). Furthermore, in response to the higher competition introduced by market integration, domestic banks learn from foreign banks and other institutions and tend to develop a better banking regulatory system (Caprio and Honohan, 1999). As a result, we expect domestic banks to become more effective information producers in the IPO process, improving the financial intermediation process and, according to the information extraction theory, leading to a lower overall level of underpricing. Finally, and strictly for IPOs, Caglio et al. (2016) and Doidge et al. (2013) point out that financial globalization increases the likelihood and reduces the cost of domestic companies going public abroad, providing companies with an opportunity to escape from poor institutional settings in their home countries - e.g. Doidge et al. (2013) find that the number of global IPOs is increased by world financial globalization.

All these arguments indicate a negative relationship between the level of financial market integration and IPO underpricing, and therefore we form the first hypothesis as follows:

H1: Financial market integration decreases the cost of listing as measured by IPO underpricing.

\section{Moderation effect of financial market integration on IPO underpricing}

Alongside a direct relationship between financial market integration and IPO underpricing, we also test the existence of an indirect mechanism. Previous cross-country studies document that country-level institutional settings can affect IPO activities and add to the explanation of underpricing. Particularly, legal settings, such as the protection for investors, law enforcement, rule of law quality, corruption level and legal origin of a country, are found to significantly affect the ex-ante uncertainty of the IPO valuation in a similar way 
as firm- and issue-level characteristics do (Banerjee et al., 2011, Engelen and Essen, 2010, Hopp and Dreher, 2013).

However, a rise in the level of financial integration weakens the influence of country institutions on corporate finance activities. Generally, this argument arises from the fact that financial integration allows a greater flexibility as companies can use foreign markets to choose the most suitable country institutions to be subjected to. A strong but also implicitly reasonable argument is made by Stulz (2009): "in a fully integrated world, we would expect national capital markets to be irrelevant". He argues that the advantages of country institutions for domestic firms gradually disappear, with financial market integration allowing firms to choose better institutions in a foreign market and lowering the costs of international investments and capital raising (Stulz, 1999, Stulz, 2009). La Porta et al. (2006) show that the influence and effectiveness of laws regulating the issuance and trading of securities in a country are heavily linked to the development of the underlying financial market. However, the impact of such laws is weakened in more open capital markets where firms can freely choose to subject themselves to the laws of other countries. Similarly, Kho et al. (2009) find increasing financial market integration decreases the importance of country institutions on corporate finance and governance activities over time. Particularly, Doidge et al. (2007) argue that the impact of country institutions on IPO activities are weakened by more accessible global capital markets, while Doidge et al. (2013) show that world financial integration increases the number of global IPOs and weakens the effects of country institutions on the number and size of both domestic and global IPOs. Therefore, they argue that financial globalization plays a weakening role for country institutions for IPO activities.

Following this line of research, we extend the literature by examining the role of financial integration as a moderation effect that weakens the role of country institutions in explaining the cross-country variation of IPO underpricing. Therefore, our second hypothesis is formulated as follows:

H2: Financial market integration weakens the impact of a country's institutions on IPO underpricing. 


\section{Data and methodology}

\section{Sample and variables}

Data on worldwide IPOs from January 1995 to December 2017 is collected from Thomson ONE New Issues Database, while market-level data is sourced from Thomson Reuters DataStream Professional. We obtain IPO information on both offering and firsttrading-day closing price to measure the level of IPO underpricing. In line with previous studies, we initially exclude companies in the finance, insurance and real estate industries (SIC code between 60 and 67) and companies with missing observations. From a total of 14,587 deals, we apply a filtering process to obtain a final full sample of 12,778 IPOs from 37 countries by removing: IPOs with abnormal initial returns outside the $-67 \%$ to $+2,000 \%$ range (likely due to measurement errors); ${ }^{5}$ IPOs using a private placement; IPOs in countries recognised as tax-haven non-sovereign jurisdictions (e.g. Bermuda and British Virgin Islands); outliers of initial returns in the top and bottom 1\% percentiles; and deals in countries with less than 5 IPOs during the overall sample period.

The level of IPO underpricing is the dependent variable in our study and is measured by the initial return on the first day of trading as follows:

$$
\text { Initial Return }=\frac{\text { First-day Closing Price }- \text { Offer Price }}{\text { Offer Price }}
$$

As the market return is negligible compared to the level of underpricing, we do not adjust for it, in line with most of the previous empirical studies.

The main variable of interest in our study is the level of financial market integration of the country where the company is listed for the first time. As an IPO represents an important event in the stock market and is heavily influenced by stock market conditions, we focus on the actual integration of the stock market among other possible measures of globalization and integration. To measure financial market integration, we follow the method developed by Pukthuanthong and Roll (2009) and compute the actual market integration by focusing on the explanatory power of a multi-factor model on global market factors. The Rsquared of such a multi-factor model represents the country's level of financial market integration with global markets. Rather than using correlations, this measure captures the

5 This selection criterion is used by Banerjee et al. (2011). 
extent to which market returns are explained by global and domestic factors. In addition, as this measure is based on daily returns, we are able to capture the time-variance within countries for the entire sample period, without relying on secondary sources as is for the other four alternative measures we use in our robustness checks. We also further separate financial integration from overall market development by controlling for market returns and turnover, which also show a low level of correlation with our financial integration measure.

The impact of market integration on IPO underpricing is tested after controlling for firm- and issuing-level characteristics. In particular, IPO size (LSIZE) is used to proxy for the ex-ante uncertainty about the issuing company, as proposed by Beaty and Ritter (1986), and some dummy variables capture whether the IPO is venture capital-backed $(V B)$ and/or uses a bookbuilding method $(B B)$, both factors reducing underpricing through a process of information revelation. Secondly, we control for market-related variables. According to Loughran and Ritter (2002) and Ljungqvist et al. (2006), the market return represents the market sentiment and is positively related to underpricing. We include the three-month cumulative market return (MRETURN) before the IPO issuing date and expect a positive relationship with underpricing. We also control for cyclical patterns in the IPO market. Particularly, we define the volume variable (VOLUME) as the ratio between the number of IPOs in a specific year in one country divided by the total number of IPOs in that country during the overall sample period ${ }^{6}$. A negative relationship between the IPO underpricing and IPO volume in the market is recorded by Ibbotson and Jaffe (1975), Lowry and Schwert (2004) and Shi et al. (2013). We also include the market turnover (TURNOVER) to further control for market development. The data is collected from Thomson Reuters DataStream for each country.

While earlier studies report a negative effect of underwriter's reputation on IPO underpricing, this relationship is reversed in more recent studies. Nonetheless, the underwriters play an undeniably important role in IPO events. Following Megginson and Weiss (1991) and Shi et al. (2013), we measure the quality of underwriters by their shares in the IPO market and create a global underwriter reputation proxy (UNDERWRITER), taking the total proceeds underwritten by each underwriter as a share of the total proceeds raised across our sample period.

\footnotetext{
${ }^{6}$ This variable is calculated based on the IPOs recorded in the database before we apply any of the filtering criteria.
} 
To test the second hypothesis, we include five alternative country-level institutional variables based on previous empirical studies (Banerjee et al., 2011, Engelen and Essen, 2010, Hopp and Dreher, 2013). They vary across countries but not across time. ${ }^{7}$ Particularly, we exclude the level of disclosure because the variable is computed using a survey in 2000 and it does not cover all countries in our study. Its use would require us to drop $25 \%$ of our sample, with particular emphasis on markets that are generally less financially integrated. Moreover, the use of a time-invariant measure does not reflect the changing nature of disclosure regulation, especially in developing and emerging markets, which represent a significant component of our study. The five country-level institutional variables are described below.

The Investor Protection Index (IPI) measures the level of minority investor protection and has a negative impact on underpricing (Banerjee et al., 2011, Engelen and Essen, 2010). In countries where minority investors are not sufficiently protected, they tend to have less monitoring power over managers and big institutional investors, and they suffer from inappropriate managerial activities (e.g. self-dealing activities). In IPO events, the high uncertainty around a company valuation makes investors reluctant to participate, as they might become minority investors. As a result, higher underpricing is required to attract them. Unlike Banerjee et al. (2011) and Engelen and Essen (2010), who use the anti-self-dealing index constructed by Djankov et al. (2008) to capture the level of minority investor protection, we use the Investor Protection Index (IPI), the most recent data on the level of minority investor protection, reported as part of the Doing Business project by the World Bank. The data is collected from the related website ${ }^{8}$ and ranges from 0 to 10 , where higher values represent a better protection for minority investors.

By dividing a country's law system into "law in books" (written laws) and "law in action" (the effectiveness of legal enforcement), Engelen and Essen (2010) find that when the "law in books" is relatively weak to protect investors from controlling insiders and unjust deals, strong legal enforcement (i.e. effective police force or courts) can to some extent compensate the weak investor protection. We obtain the Public Enforcement Index (PEI) as a proxy for the effectiveness of the legal enforcement system from La Porta's website. ${ }^{9}$ The index ranges from 0 to 1 , with higher values representing more effective legal enforcement.

\footnotetext{
${ }^{7}$ This is a standard approach in the literature, also considering that there is very little (and insignificant) timevariation.

8 Source: http://www.doingbusiness.org/

${ }^{9}$ Source: http://faculty.tuck.dartmouth.edu/rafael-laporta/research-publications/
} 
Furthermore, we also include the Rule of Law Index (RLI) and the Corruption Perception Index (CPI) to proxy for the overall quality of a country's legal system (Engelen and Essen, 2010). The Rule of Law Index is constructed by the World Justice Project ${ }^{10}$ and ranges between 0 and 1, with higher values representing better overall legal systems. The Corruption Perception Index is provided by Transparency International ${ }^{11}$ and measures the level of corruption, ranging from 0 (most corrupted environment) to 100 (least corrupted environment).

Finally, ENGLISH represents a dummy variable that captures the status of a country's legal origin. It equals 1 if its legal system is originated from English Common Law and 0 otherwise. The data on legal origin is collected from La Porta et al. (1998). La Porta et al. (1998) find that the legal protection is generally better in common law countries (i.e. USA and UK) than in civil law countries (i.e. Germany, France and Scandinavian countries). Hence, following the literature, we expect a lower level of underpricing in countries with an English Common Law system.

\section{[ INSERT TABLE 1 HERE ]}

\section{Summary statistics}

Table 1 defines the main variables in our study and shows data sources and summary statistics. We report a high level of underpricing, on average $27.46 \%$, associated with a significant standard deviation of $49.40 \%$. This shows the significance of the phenomena and the high level of variation over time and across companies and countries. In light of the high variation, it will be important to control for several cross-sectional and time effects.

\section{[ INSERT TABLE 2 HERE ]}

Table 2 summarizes the average IPO underpricing at country level from 1995 to 2017. We notice a large variation in the level of underpricing and the number of IPOs across countries. In our sample, the US has the highest number of observations with 3,955 IPOs, followed by China and Australia with 2,729 and 960 respectively. Our dataset is by far the

\footnotetext{
${ }^{10}$ For more details about how the rule of law index is constructed, please refer to the World Justice Project website. http://worldjusticeproject.org/

11 Transparency International is an independent organisation that monitors the level of corruption in the world. Regarding the construction of the corruption perception index, please refer to their website. https://www.transparency.org/
} 
largest in cross-country IPO studies. ${ }^{12}$ During the sample period, all 37 countries experience underpricing. China has the highest level at $43.11 \%$, with Hong Kong following at $42.77 \%$, while Norway records the lowest figure at $2.33 \%$ based on 62 IPOs. Brazil shows an average underpricing of 5.62\%, which differs from 33.1\% in Loughran et al. (1994, updated 2015). We explain this difference arguing that our 1995 to 2017 sample period is much more recent than their 1979 to 2011 period. Moreover, a recent study by Minardi et al. (2015) reports a $4.5 \%$ average underpricing for Brazilian IPOs using a similar sample period to ours (2004 to 2012). Therefore, we believe our sample not affect the main findings of this study. ${ }^{13}$

\section{[ INSERT TABLE 3 HERE ]}

In our second hypothesis, we test the moderation effect that financial market integration plays on the relationship between country institutions and underpricing. Table 3 Panel A presents the average level of market integration and alternative measures by country. Our variable of interest, market integration $(M I)$, presents similar values to those in Pukthuanthong and Roll (2009). Examples of markets with low levels of financial integration are Argentina, China, India, Indonesia and the Philippines, while Australia, France, Germany, Hong Kong, Singapore, UK and US are among markets with high financial integration.

Table 3 Panel B presents the variables used to proxy for different country-level institutional settings. Firstly, the correlation of different proxies is encouraging as it shows similar patterns across countries. The Investor Protection Index finds financially dominated countries such as Hong Kong and Singapore among the highest ranked, while countries such as the Philippines and China are among the worst in protecting investors' interests. To our surprise, Luxembourg shows a low protection and the US, Germany and Sweden are only positioned around the average (even if still ranked above many other countries we would expect to have a lower protection). We find an explanation for this puzzle in the next index, which measures the effectiveness of legal enforcement. In fact, the aforementioned countries show the highest value of enforcement, alongside Canada, Sweden and others. The US however, still remains a puzzle, but it is solved when the characteristics of the overall legal

\footnotetext{
${ }^{12}$ The ranking of the underpricing by country is highly correlated (0.6) with the one reported in Jay Ritter's website, but single average figures show some differences due to the use of different sample periods. Most Jay Ritter's country IPO data goes back to the 1970s, while ours starts in the 1990s. The representativeness of our sample is also confirmed by the high correlation (0.7) of our underpricing figures with Banerjee et al. (2011).

${ }^{13}$ As robustness check, we have run the models excluding IPOs from Brazil and the results do not change.
} 
system are considered (Rule of Law Index). In fact, the US is ranked top with other more efficient markets such as Australia, Canada, Hong Kong, Japan, Singapore, Scandinavian countries and the UK. Similar results are also found for the Corruption Perception Index, which shows a very high correlation (0.97) with the Rule of Law Index. Finally, we find that $34 \%$ of the countries in our study are based on the English Common Law.

\section{Hierarchical linear modelling}

An OLS estimation is a commonly adopted method in IPO literature. Since our data clearly shows a hierarchical structure with IPOs nesting within the same country sharing similar patterns, hierarchical linear modelling (HLM) - Raudenbush and Bryk (1992) allows us to test our hypotheses on country institutions and control for country effects at the same time, without violating the independence assumption of residuals. This methodology is also used in the cross-country IPO underpricing study by Engelen and Essen (2010). As Garson (2013) points out, in the presence of a nesting or clustering structure, observations from the same group are not independent and the standard errors of the predicted parameters by an OLS regression are underestimated. As a result, wrong or imprecise inferences might be made.

Particularly, we use a two-level HLM, where levels 1 and 2 represent respectively individual IPOs and countries (treated as a random sample from a wider population). As a rule of thumb, a good HLM estimation needs at least 20 observations at level 2, and our dataset meets this requirement with 37 countries included. Among the different specifications of an HLM, we use a random intercept model, which allows for the level 1 intercept to shift between countries (i.e. the random factor is the country variable where correlated errors are created and slopes are parallel lines between countries ${ }^{14}$ ). In the random intercept model, the intercept of the IPO performance at level 1 is then modelled as a random effect of the relative country at level 2 . The specification for hypothesis 1 is as follows:

$$
\text { H1: } U_{i j t}=\beta_{0}+\beta_{1} \text { Integration }_{j t}+\beta_{2} X_{i j t}+\mu_{j}+\epsilon_{i j t}
$$

\footnotetext{
${ }_{14}$ The other model is the random slope model, which allows the slope to differ across countries too. In order to choose between these two models, we use a likelihood ratio test and the random intercept model is more appropriate.
} 
where $U_{i j t}$ is the underpricing level for IPO $i$ in country $j$ in year $t$; Integration Int $_{\text {in }}$ the level of financial integration for country $j$ in year $t ; X_{i j t}$ represents a vector of the control variables; $\mu_{j}$ is the random country effect shifting the regression line between countries; and $\epsilon_{i j t}$ is the overall error term at level $1 .^{15}$

Alongside an HLM estimation, we also present the OLS results with random country effects, which generally support our main findings. Finally, to test that IPO underpricing is indeed affected by market integration rather than other unobserved factors or self-selection of companies in stock exchanges with high versus low market integration, we employ a treatment effect estimation with propensity score matching. We categorize IPOs into a highintegration group if the listing country of this IPO has an above-average market integration in the issuing year and a low-integration group otherwise. The dummy variable of high versus low integration acts as a "treatment" effect, where each IPO in the high-integration group is matched to an IPO in the low-integration group whose propensity score is closest. In our estimation, the propensity score is obtained by using a logit model on $V B, B B, L S I Z E$, VOLUME, MRETURN, TURNOVER and UNDERWRITER.

Along with the presence of a direct effect, we also argue that financial market integration of a country works as a moderation effect, which weakens the explanatory power of the country institutions in the cross-country variation of IPO underpricing. As mentioned in the data section above, we include five different country-level institutional variables. In order to test for the moderation effect, we follow the method used in Doidge et al. (2013). The interaction term between financial integration and each of the five institutional variables is adopted to capture that effect. As Baron and Kenny (1986) suggest, the specification should also include the two main effects in the interaction term. Our specification is as follows:

H2: $\quad U_{i j t}=\beta_{0}+\beta_{1} M I_{j t}+\beta_{2} I_{j}+\beta_{3}\left(M I_{j t} * I_{j}\right)+\beta_{4} X_{i j t}+\mu_{j}+\epsilon_{i j t}$

\footnotetext{
${ }^{15}$ Note that the random effect $\mu_{j}$ and the overall error term $\epsilon_{i j t}$ are independent of each other.
} 
where $I_{J}$ is the institutional variable for country $j^{16}$; the variable of interest, $\left(M I_{j t} *\right.$ $\left.I_{j}\right)$, is the interaction term between the level of market integration of country $j$ and the country $j$ institutional variable. All other variables are the same as in Equation (3).

We start with a two-level null model to partition the variance in level 1 and level 2. For parsimonious reasons, and also considering that the model is simple, we do not report the intermediate results. The between-country variance is 111.12 and the level 1 variance is 2319.56. Therefore, the between-country differences could explain about $5 \%$ of the variance in the cross-country IPO underpricing.

\section{Main results}

\section{Tests on the direct effect of financial market integration}

Table 4 reports the main results for hypothesis 1 , the direct effect of financial integration on IPO underpricing. We focus our discussion on the coefficients reported in Model (1), which reports the baseline model using the main proxy for the level of financial market integration. To make the results comparable, Market Integration $(M I)$ used in the regressions are presented in percentages. Consistent with our expectation, we find that market integration reduces the level of IPO underpricing, improving the valuation certainty through a more efficient intermediation process. It also supports the argument in the law and finance literature that the cost of external financing caused by information asymmetry and agency costs is reduced by increasing financial globalization (Stulz, 1999). A one standard deviation increase in $M I$ results in 0.28 standard deviation decrease in the level of IPO underpricing. A coefficient of -0.358 suggests that a $2.8 \%$ increase in $M I$ translates into a $1 \%$ decrease in the level of underpricing, all else equal. This finding represents the first major contribution of our study to the literature on international IPO studies.

\section{[ INSERT TABLE 4 HERE ]}

Consistent with most of the previous empirical findings, firm- and issuing-level control variables generally show the expected signs. Many of the early studies based on the

\footnotetext{
${ }^{16}$ All country-level institutional variables are held constant throughout the sample period for each country, which is a common approach in the literature.
} 
US market find a negative relationship between the venture-capital status and the level of underpricing, supporting the certification role of venture capitalists proposed by Megginson and Weiss (1991). They argue that the existence of venture capitalists in an IPO company certifies the "quality" of the IPO offer price - i.e. the price reveals all the relevant information and this leads to a reduction in the underpricing. However, the reversed relationship has also been documented (Boeh and Dunbar, 2016, Guo et al., 2006, Liu and Ritter, 2011), supporting the analyst lust theory by Liu and Ritter (2011). They point out that, as venture capitalists are more interested in the market price on the day shares are distributed to the limited shareholders (usually after the lock-up periods), they have a great desire to attract the all-star analysts' coverage. This can affect the IPO price leading to a higher underpricing. We find support for the analyst lust theory, as we record a positive effect of the venture-capital status on the level of underpricing.

Bookbuilding status and company size are commonly used measures for the ex-ante uncertainty about the valuation because the bookbuilding technique and big companies are normally associated with lower levels of information asymmetry. We show a negative impact of the bookbuilding technique and company size on IPO underpricing which is consistent with the majority of the empirical studies supporting the classic information-asymmetrybased theories (Benveniste and Spindt, 1989, Beaty and Ritter, 1986, Rock, 1986, Reber and Vencappa, 2016).

We report a $0.4 \%$ reduction in IPO underpricing for each percentage point of cumulative market return increase during the three months prior to the deal (MRETURN) in support of the "hot issue" period argument by Ritter (1984). This finding also provides evidence for the behavioural argument that a higher pre-IPO market return indicates higher sentiment demand from exuberant investors leading to higher initial returns (Loughran and Ritter, 2002, Ljungqvist et al., 2006, Reber and Vencappa, 2016).

Consistent with Ibbotson and Jaffe (1975), Lowry and Schwert (2004) and Shi et al. (2013), we find that IPOs issued in years with relative higher VOLUME of IPO deals experience lower underpricing. This result also supports the information revelation argument by Alt1 (2005), who identifies an unknown common factor driving IPO valuations. The private information about the common factor is gradually revealed by the outcomes of previous IPOs because the IPO offer price incorporates the indications of the participating investors' interests. 
The coefficient on UNDERWRITER is significantly positive, suggesting that a higher reputation increases the underpricing, as found in several recent studies.

\section{[ INSERT TABLE 5 HERE ]}

Furthermore, we compare the HLM estimates with simple OLS estimates. Results are presented in Model (1) in Table 5. According to Garson (2013), even though the second level random factor should have no effects on the means of individual observations in the first level, it can change the covariance structure, hence leading to inefficient estimates by reducing standard errors. We find that the OLS results confirm the ones obtained using HLM, except for an underestimation of the impact of financial integration on underpricing by circa $35 \%$. The differences in our results are due to the random factors at level 2, which are not explicitly modelled in the OLS estimation. We also test for model preference using a likelihood ratio, which indicates that the HLM accounting for the country random effect is the preferred model. Notwithstanding the normal use of simple OLS models in international IPO studies, we find overall confirmation that an HLM structure should be adopted to research a micro-level phenomenon (underpricing) using a macroeconomic country-level argument. This finding represents one of the major contributions of our study.

\section{[ INSERT TABLE 6 HERE ]}

The final step to test the direct impact of market integration on IPO underpricing is to estimate a propensity score matching (PSM) model. Table 6 shows that the overall benefit of listing a company in a highly integrated market corresponds to a $10 \%$ reduction in IPO underpricing - Model (1). Our PSM results are consistent with HLM and OLS estimations.

\section{Tests on the moderation effect of financial market integration}

The baseline results for hypothesis 2 , the indirect effect of financial integration, are presented in Table 7. Models (1) to (5) each include a different proxy of the country-level institutional variables. Overall, the inclusion of country institutions in our models does not alter the significant negative impact of financial integration on IPO underpricing. At the same time, we find that a better legal protection of minority investors $(I P I)$ and quality of legal framework $(R L I)$, more effective public enforcement $(P E I)$, a lower level of corruption $(C P I)$ 
and the existence of an English common law-based system (ENGLISH) in a country reduce the uncertainty of the ex-ante IPO valuation as well as the level of underpricing. This is consistent with previous cross-country IPO studies.

However, the significantly positive coefficient of the interaction term (MIx Institution) signals that market integration acts as a moderator effect, reducing the extent to which country institutions affect the level of IPO underpricing. In other words, in a country that is more financially integrated with the global markets, institutional characteristics show a weaker effect on the IPO underpricing. This finding supports our second hypothesis and the argument in the law and finance literature that financial globalization weakens country institutions. It is also consistent with Doidge et al. (2013), who find that the world financial globalization reduces the impact of country institutions on IPO size and numbers.

\section{[ INSERT TABLE 7 HERE ]}

This is particularly evident in Model (1), where the negative relationship between the level of minority investor protection (IPI) and the level of IPO underpricing is consistent with Banerjee et al. (2011), Engelen and Essen (2010) and Hopp and Dreher (2013). They all argue that more underpricing is required to compensate the minority investors in a country where the investor's protection is insufficient. We show that this effect is weakened by the improvements in the level of financial integration. Models (2), (3), (4) and (5) also show a reduction in the direct negative relationship between underpricing and the level of Public Enforcement Index $(P E I)$, the Rule of Law Index $(R L I)$, the Corruption Perception Index $(C P I)$ and the English common law dummy (ENGLISH) due to higher levels of market integration. Finally, the coefficients of all control variables are still consistent with the baseline Model (1) reported in Table 4.

The interpretation of the interaction term between continuous variables is not as straightforward as the one between categorical variables. For example, in Model (5) the high absolute value of ENGLISH indicates that the average IPO underpricing in English common law countries is $23 \%$ lower than elsewhere. However, the positive coefficient of the interaction term indicates that this prominent impact is somewhat weakened by the increase in the level of financial integration. When the level of market integration increases by $1 \%$, the decrease in the average underpricing caused by the English common law system is reduced by $0.28 \%$. 
Since market integration and institutional variables are both continuous variables in Models (1) to (4) we also estimate the second hypothesis by re-centring market integration at one standard deviation below (4a) or above (4b) its mean as follows:

$$
\begin{gathered}
M I_{-} L o w=M I-\left(\operatorname{mean}_{M I}-1 s d\right) \\
M I \_H i g h=M I-\left(\text { mean }_{M I}+1 s d\right) .
\end{gathered}
$$

This procedure allows us to hold the market integration constant at "low" - MI_Low in Equation (4a) - and "high" - MI_High in Equation (4b) - values and to compute the slopes of the country institutional variables under these two scenarios.

With market integration assuming a value of zero, $\beta_{2}$ in Equation (3) represents the impact of country institutions $(I)$ on IPO underpricing. However, the level of market integration is unlikely to reach a value of zero or below. Hence, by subtracting $\left(m^{2} a n_{M I}-\right.$ $1 s d)$ or $\left(\operatorname{mean}_{M I}+1 s d\right)$ from $M I$, a value of zero for the newly constructed market integration measure is made meaningful. For example, MI_Low (MI_High) can take the value of zero when market integration is held constant at one standard deviation below (above) its mean $\left(\right.$ mean $\left._{I F I}-1 s d\right)\left(\left(\right.\right.$ mean $\left.\left._{I F I}+1 s d\right)\right)$. The interpretation of $\beta_{2}$ becomes straightforward as it simply represents the effect of country institutions on the level of underpricing, given a constant low (high) level of financial integration - one standard deviation below (above) the mean. Therefore, comparing the slopes on country institutional variables when market integration moves from low to high values, we expect the slope to flatten (i.e. the absolute value of the $\beta_{2}$ coefficient to decrease).

\section{[ INSERT TABLE 8 HERE ]}

Estimated coefficients are reported in Table 8. Models (1) to (4) present estimations for four different country institutions respectively: IPI, PEI, RLI and CPI. Under each model, we report two equations for market integration held at low (a) or high (b) values respectively. Interaction_Low and Interaction_High are the interaction terms between each of the country institutions and MI_Low and MI_High respectively. As all estimates of control variables remain similar to our baseline results in Table 7, we do not report them here. As expected, 
Model (1) shows that the absolute value of the coefficient for IPI decreases when market integration moves from low (Model (1a)) to high (Model (1b)) values. More specifically, a one unit increase in the level of investors' protection results in an $10.44 \%$ decrease in average underpricing when market integration is held at one standard deviation below its mean, while the decrease is reduced to $5.15 \%$ when market integration is increased by two standard deviations (one standard deviation above its mean). The same pattern is found on the remaining country institutional variables. Interestingly, we find that, for some country institutions, market integration not only decreases the impact on IPO underpricing, but also changes the direction of the impact. One possible explanation is that countries with goodquality institutions might be "punished" by integrating deeply with global markets, which have on average lower quality institutions than theirs. This is in line with the argument that developing countries benefit more from the globalization process than developed countries. Overall, the empirical results reported in Table 8 further support our second hypothesis and reinforce the evidence of the moderation effect of market integration. Further robustness tests are reported in the next section.

\section{Robustness tests}

To test that our results are not driven by the choice of a specific financial integration measure, we also use alternative measures to estimate models for hypothesis 1. Firstly, we employ the KOF Index of Globalization ${ }^{17}$ and, similar to Doidge et al. (2013), we focus on one of its Economic Globalization Index $(E G)$. This measure is constructed using an equally weighted combination of the de facto $\left(E G \_d f\right)$ and de jure $\left(E G \_d j\right)$ measures of Economic Globalization. We use these two indices separately. A sub-index in $E G$ measures the financial market integration, which is closer to our market integration measure. Therefore, we also include the de facto (Finance_df) and de jure (Finance_dj) measures of financial integration separately. Finance_df is the sum of external assets and liabilities as a share of GDP, a method firstly developed by Lane and Milesi-Ferretti (2003) and revised in Lane and MilesiFerretti (2007). Finance_dj measures the country's capital account openness based on its restrictions on the cross-border financial transactions, a metric developed by Chinn and Ito

\footnotetext{
17 The KOF index is constructed by the KOF Swiss Economic Institute and is updated annually. The overall index consists of $36 \%$ economic globalization, $37 \%$ social globalization and $27 \%$ political globalization. The data and details on the index construction are available on the website: http://globalization.kof.ethz.ch/.
} 
(2006). Results reported in Models (2) to (4) in Table 4 are very similar to the original baseline results in Model (1). A $1 \%$ increase in $E G_{-} d f\left(E G_{-} d j\right)$ results in a $0.33 \%(0.5 \%)$ decrease in the level of IPO underpricing. This impact increases to $0.45 \%$ and $0.5 \%$ in Models (4) and (5), indicating that financial market integration seems to have a stronger impact than the overall economic globalization. On the whole, we confirm the significant effects of the financial integration on IPO underpricing.

We also use all these alternative proxies in our OLS estimation, reporting results in Models (2) to (5) within Table 5. They further confirm our main findings. Furthermore, we employ the four alternative proxies of financial integration in the propensity score matching (PSM) estimation and present findings in Table 6. Our PSM results in Models (2) to (5) are consistent with HLM and OLS estimations and show robustness to the use of alternative proxies of financial integration.

In the main result section, we strengthen the inference of our second hypothesis (moderator effect) by holding the market integration constant at high and low levels (see Table 8). We further test the robustness of our results replacing our main measure of market integration with the Economic Globalization Index $(E G)$ in Table 9. The coefficients for $E G$, country institutions, interaction terms and control variables are all similar to the baseline results presented in Table 7.

\section{[ INSERT TABLE 9 HERE ]}

Furthermore, a general concern linked to the inclusion of an interaction term is the increased multicollinearity, which might affect the precision of our inference. To test for the impact of increased collinearity on our estimation, we follow Aiken and West (1991) and Jaccard and Turrisi (2003) and mean-centre the two variables before interacting them as follows:

$$
\text { Interaction }=(M I-\text { mean_MI }) *(I-\text { mean_I })
$$

where $M I$ is the level of market integration; mean_MI is its mean across all observations; I represents a country-level institutional variable and mean_I is its mean across countries. Results are presented in Table 10, where Models (1) to (5) refer to different proxies for country institutions as in Table 7. All models show that, although the centred variables 
have different values of coefficient estimates, their effect and significance do not change, signalling that our results are not driven by a potential increased collinearity induced by the interaction term.

\section{[ INSERT TABLE 10 HERE ]}

Furthermore, we have operated several other robustness tests, the results of which are not fully reported in this paper for parsimonious reasons. Overall, our main findings withstand all following extra robustness tests.

Firstly, our findings are robust to the introduction of year dummies by using both HLM and OLS estimations, with coefficients showing values and statistical significance in line with the main models. To further support the results by HLM, we have also estimated OLS models with clustering by country and year respectively and the main findings remain consistent.

Secondly, we confirm that financial market integration reduces IPO underpricing not only for foreign IPOs but also domestic ones. We exclude all foreign IPOs and estimate the main model (with both HLM and OLS) using a reduced sample of domestic IPOs only and find no significant differences in our results. As an alternative strategy, we also interact a foreign IPO dummy variable with market integration and find confirmation for all main results on financial integration, country institutions and their interactions. While most of the specifications have returned insignificant coefficients of the interaction term between market integration and the foreign IPO dummy, some suggest that foreign IPOs might experience greater impact from market integration. In other words, while both domestic and foreign IPOs experience a decrease in underpricing when market integration increases, the scale of this decrease is greater for foreign IPOs than for domestic ones. Both tests strengthen the findings and eliminate the concerns that financial market integration of a country only impacts on foreign IPOs.

Thirdly, to test that our results are not driven by the US market - the most popular destination for foreign listings - we exclude all US IPOs and estimate HLM models on the remaining 36 countries. All main findings are statistically and economically consistent for both hypotheses. More particularly, with a negative coefficient for venture capital status $(V B)$, in countries other than the US we find support for the certification argument by Megginson and Weiss (1991) rather than analyst lust theory by Liu and Ritter (2011). Meanwhile, the 
coefficient on underwriters' reputation (UNDERWRITER) becomes insignificant, suggesting that underwriters' reputation is primarily important in the US. This finding related to the 'dark side' of financial institutions is worth exploring further.

Fourthly, to address potential correlated omitted variables, we estimate a model specification adding two country-level control variables to the baseline specification of our second hypothesis included in Table 7 . In particular, we first separately and then jointly add trade openness and home bias, which may be correlated with market integration, country institutions and IPO underpricing. Coefficient estimates show that market integration, country institutions and the interaction term are still statistically and economically significant. This estimation procedure is applied for each institutional variable used in Table 7 and results are consistent.

Finally, although the average underpricing of Brazil in our sample is similar to more recent studies, it still might raise concerns as it is significantly smaller than what is reported on Jay Ritter's website, as mentioned earlier. We then estimate models excluding Brazilian IPOs and results still hold.

\section{Conclusion}

By using a hierarchical linear modelling with nearly 13,000 IPOs from 37 countries, this study presents evidence that IPO underpricing decreases when the IPO listing market is more integrated with the global markets. In particular, we argue that a direct effect is firstly obtained through an improved efficiency of the financial intermediation process because of the increased external competition introduced by financial integration, which eventually improves the efficiency of IPO pricing for both domestic and foreign IPOs. Therefore, this effect could have two possible explanations. Firstly, companies going public domestically benefit from a higher competition in the home market, which decreases the information asymmetry and makes the pricing process more transparent. Secondly, foreign IPOs may benefit from listing in countries with an improved efficiency. Importantly, we find that this relationship is robust to the use of either de jure or de facto measures of financial integration and it does not represent a cyclical phenomenon that is restricted to a specific period.

Moreover, we identify an indirect channel where market integration reduces IPO underpricing by diminishing the role country institutions play in the development of financial markets. Once integration is accounted for, we find that the impact of country institutions on 
IPO underpricing weakens. This can be explained by companies becoming less reliant on home institutions due to the increased accessibility to the global markets. Hence, we argue that the integration of financial markets has a moderation effect, reducing the explanatory power of country institutions in IPO underpricing.

Overall, our empirical findings support the previous literature in international corporate finance, providing complementary evidence that market integration not only lowers the cost of external financing, but also weakens the role of country institutions on corporate finance decisions - e.g. Stulz (1999, 2009) and Doidge et al. (2013). By identifying the effects of financial integration, this work adds to the explanation of IPO underpricing (especially cross-country variation), and also presents a macroeconomic approach to investigate corporate finance activities.

Our findings provide issuers, underwriters and investors some insights into the role that country institutional settings play in IPO markets and how this role can be altered by improvements in market integration. Firstly, as financial integration decreases the cost of IPOs associated with underpricing and increases the capital that the issuing company can raise, it gives issuers incentives to seek more financially integrated markets for listings. Secondly, the dynamic relationship between market integration, country institutions and IPO performance is particularly informative for foreign IPO investors and issuers who consider cross-border listings to either avoid or take advantage of certain institutional characteristics. Thirdly, as emerging markets are more sensitive to the globalization process, this provides valuable implications for policy makers regarding the impact of market integration on domestic financial development as well as corporate activities. While financial integration helps to improve the efficiency of the domestic market, it also provides domestic companies with opportunities to choose foreign capital by reducing constraints from institutional settings, e.g. legal frameworks. Therefore, a sustainable development would be linked to an improvement in the institutional settings and legal framework while taking advantage of the integration process.

Finally, we envisage the scope of this work to develop in two main directions. First, as we argue that the direct effect is transmitted through the financial intermediation process, one could further test this mechanism by examining how the gross spread and market share of investment banks are affected. Second, as this work uses a static cross-sectional measure of legal systems, the impact and role of the dynamic development of legal systems and its 
interaction with improvements in financial market integration may be tested in relation to the valuation of IPOs. 


\section{References}

AgéNor, P.-R. 2003. Benefits and costs of international financial integration: theory and facts. The World Economy, 26, 1089-1118.

Aiken, L. S. \& West, S. G. 1991. Multiple Regression: Tesing and Interpreting Interactions., Newbury Park, CA, Sage Publications.

Allen, F. \& Faulhaber, G. R. 1989. Signalling by underpricing in the IPO market. Journal of Financial Economics, 23, 303-323.

Alt1, A. 2005. IPO market timing. Review of Financial Studies, 18, 1105-1138.

Banerjee, S., Dai, L. \& Shrestha, K. 2011. Cross-country IPOs: what explains differences in underpricing? Journal of Corporate Finance, 17, 1289-1305.

Baron, R. M. \& Kenny, D. A. 1986. The moderator-mediator variable distinction in social psychological research: conceptual, strategic, and statistical considerations. Journal of Personality and Social Psychology, 51, 1173-1182.

Barry, C. B., Muscarella, C. J., Peavy, J. W. I. \& Vetsuypens, M. R. 1990. The role of venture capital in the creation of public companies: evidence from the going-public process. Journal of Financial Economics, 27, 447-471.

Beaty, R. P. 1989. Auditor reputation and the pricing of initial public offerings. The Accounting Review, 64, 693-709.

Beaty, R. P. \& Ritter, J. R. 1986. Investment banking, reputation, and the underpricing of initial public offerings. Journal of Financial Economics, 15, 213-232.

Benveniste, L. M. \& Spindt, P. A. 1989. How investment bankers determine the offer price and allocation of new issues. Journal of Financial Economics, 24, 343-361.

Boeh, K. K. \& Dunbar, C. 2016. Underwriter deal pipeline and the pricing of IPOs. Journal of Financial Economics, 120, 383-399.

Brailsford, T., Heaney, R. \& Shi, J. 2004. Modelling the behaviour of the new issue market. International Review of Financial Analysis, 13, 119-132.

Brennan, M. J. \& Franks, J. 1997. Underpricing, ownership and control in initial public offerings of equity securities. Journal of Financial Economics, 45, 391-413.

Caglio, C., Hanley, K. W. \& Marietta-Westberg, J. 2016. Going public abroad. Journal of Corporate Finance, 41, 103-122.

Caprio, G. \& Honohan, P. 1999. Restoring banking stability: beyond supervised capital requirements. Journal of Economic Perspectives, 13, 43-64.

Carter, R., Dark, F. H. \& Singh, A. K. 1998. Underwriter reputation, initial returns and the long-run performance of IPO stocks. Journal of Finance, 53, 285-311.

Carter, R. \& Manaster, S. 1990. Initial public offerings and underwriter reputation. . Journal of Finance, 45, 1045-1068.

Chemmanur, T. J. \& Fulghieri, P. 1994. Investment bank reputation, information production, and financial intermediation. . Journal of Finance, 49, 57-79. 
Chinn, M. D. \& Ito, H. 2006. What matters for financial development? Capital controls, institutions, and interactions. Journal of Development Economics, 81, 163-192.

Derrien, F. 2005. IPO pricing in "hot" market conditions: who leaves money on the table? Journal of Finance, 60, 487-521.

Djankov, S., La Porta, R., Lopez-De-Silanes, F. \& Shleifer, A. 2008. The law and economics of self-dealing. Journal of Financial Economics, 88, 430-465.

Doidge, C., Andrewkarolyi, G. \& Stulz, R. 2007. Why do countries matter so much for corporate governance? Journal of Financial Economics, 86, 1-39.

Doidge, C., Karolyi, G. A. \& Stulz, R. M. 2013. The U.S. left behind? Financial globalization and the rise of IPOs outside the U.S. Journal of Financial Economics, 110, 546-573.

Ellis, K., Michaely, R. \& O'hara, M. 2000. When the underwriter is the market maker: an examination of trading in the IPO aftermarket. Journal of Finance, 55, 1039-1074.

Engelen, P.-J. \& Essen, V. M. 2010. Underpricing of IPOs: firm-, issue- and country-specific characteristics. Journal of Banking \& Finance, 34, 1958-1969.

Garson, G. D. 2013. Fundamentals of hierarchical linear and multilevel modeling. In: GARSON, G. D. (ed.) Hierarchical linear modeling: guide and applications. London: SAGE.

Gompers, P. A. 1996. Grandstanding in the venture capital industry. Journal of Financial Economics, 42, 133-158.

Grinblatt, M. \& Hwang, C. Y. 1989. Signalling and the pricing of new issues. Journal of Finance, 44, 393-420.

Guo, R.-J., Lev, B. \& Shi, C. 2006. Explaining the short- and long- term IPO anomalies in the US by R\&D. Journal of Business Finance \& Accounting, 33, 550-579.

Hausler 2002. The globalization of finance. Finance \& Development. IMF.

Hong, H. A., Hung, M. \& Lobo, G. J. 2014. The impact of mandatory IFRS adoption on IPOs in global capital markets. The Accounting Review, 89, 1365-1397.

Hopp, C. \& Dreher, A. 2013. Do differences in institutional and legal environments explain cross-country variations in IPO underpricing? Applied Economics, 45, 435-454.

Ibbotson, R. G. \& Jaffe, J. F. 1975. "Hot issue" markets. Journal of Finance, 30, 1027-1042.

Jaccard, J. \& Turrisi, R. 2003. Interaction Effects in Multiple Regression., SAGE.

Kho, B.-C., Stulz, R. M. \& Warnock, F. E. 2009. Financial globalization, governance, and the evolution of the home bias. Journal of Accounting Research, 47, 597-635.

Kose, M. A., Prasad, E., Rogoff, K. \& Wei, S.-J. 2010. Financial globalization and economic policies. In: RODRIK, D. \& ROSENZWEIG, M. (eds.) Hnadbook of development economics. Netherlands: Elsevier.

La Porta, R., Lopez-De-Silanes, F., Shleifer, A. \& Vishny, R. W. 1998. Law and finance. Journal of Polotical Economy, 106, 1113-1155.

Lane, P. R. \& Milesi-Ferretti, G. M. 2003. International financial integration. IMF Staff Papers.

Lane, P. R. \& Milesi-Ferretti, G. M. 2007. The external wealth of nations mark II- rivised and extented estimates of foreign assets and liabilities, 1970-2004. Journal of International Economics, 73, 223-250. 
Lerner, J. 1994. Venture capitalists and the decision to go public. Journal of Financial Economics, 35, 293-316.

Liu, X. \& Ritter, J. R. 2011. Local underwriter oligopolies and IPO underpricing. Journal of Financial Economics, 102, 579-601.

Ljungqvist, A., Nanda, V. \& Singh, R. 2006. Hot markets, investor sentiment, and IPO pricing. Journal of Business, 79, 1667-1702.

Loughran, T. \& Ritter, J. R. 2002. Why don't issuers get upset about leaving money on the table in IPOs? Review of Financial Studies, 15, 414-443.

Loughran, T., \& Ritter, J. R. 2004. Why has IPO underpricing changed over time? Financial Management, 33, 5-37.

Loughran, T., Ritter, J. R. \& Rydqvist, K. 1994, updated in 2015. Initial public offerings: international insights. Pacific-Basin Finance Journal, 2, 165-199.

Lowry, M. \& Schwert, G. W. 2004. Is the IPO pricing process efficient? Journal of Financial Economics, 71, 3-26.

Megginson, W. L. \& Weiss, K. A. 1991. Venture capitalist certification in initial public offerings. Journal of Finance, 46, 879-903.

Minardi, A. M. a. F., Moita, R. M. \& Castanho, R. P. 2015. Investigating the partial adjustment effect of Brazilian IPOs. Journal of Business Research, 68, 189-198.

Nanda, V. \& Youngkeol, Y. 1997. Reputation and financial intermediation: an empirical investigation of the impact of IPO mispricing on underwriter market value. Journal of Financial Intermediation, 6, 39-63.

Pukthuanthong, K. \& Roll, R. 2009. Global market integration: an alternative measure and its application. Journal of Financial Economics, 94, 214-232.

Raudenbush, S. W. \& Bryk, A. S. 1992. Hierarchical linear models : applications and data analysis methods., London, SAGE.

Reber, B. \& Vencappa, D. 2016. Deliberate premarket underpricing and aftermarket mispricing: new insights on IPO pricing. International Review of Financial Analysis, 44, 1833.

Ritter, J. R. 1984. The hot issue market of 1980. Journal of Business, 57, 215-240.

Ritter, J. R. \& Welch, I. 2002. A review of IPO activity, pricing, and allocations. Journal of Finance, 57, 1795-1828.

Rock, K. 1986. Why new issues are underpriced. Journal of Financial Economics, 15, 187212.

Sherman, A. 2005. Global trends in IPO methods: book building versus auctions with endogenous entry. Journal of Financial Economics, 78, 615-649.

Shi, C., Pukthuanthong, K. \& Walker, T. 2013. Does disclosure regulation work? Evidence from international IPO markets. Contemporary Accounting Research, 30, 356-387.

Stulz, R. M. 1999. Globalization, corporate finance and the cost of capital. Journal of Applied Corporate Finance, 12, 8-25.

Stulz, R. M. 2009. Securities laws, dsclosure, and national capital markets in the age of financial globalization. Journal of Accounting Research, 47, 349-390. 
Tinic, S. M. 1988. Anatomy of initial public offerings of common stock. Journal of Finance, $43,789-822$.

Welch, I. 1989. Seasoned offerings, imitation costs, and the underpricing of initial public offerings. Journal of Finance, 44, 421-449. 
Table 1: Variables description and descriptive statistics

\begin{tabular}{|c|c|c|c|c|c|c|}
\hline \multirow{2}{*}{ Variable } & \multirow{2}{*}{ Description } & \multicolumn{5}{|c|}{ Statistics } \\
\hline & & Obs & Mean & StD & Min & Max \\
\hline$I R$ & $\begin{array}{l}\text { Initial Return }(\%) \text {, which measures the level of underpricing as the difference } \\
\text { between the offer price and the closing price on the first trading day. Source: } \\
\text { Thomson One }\end{array}$ & 12778 & 27.46 & 49.40 & -58.33 & 890.00 \\
\hline$V B$ & $\begin{array}{l}\text { A dummy variable that equals } 1 \text { if the IPO is venture capital backed; } 0 \text { otherwise. } \\
\text { Source: Thomson One }\end{array}$ & 12735 & 0.28 & 0.45 & 0.00 & 1.00 \\
\hline$B B$ & $\begin{array}{l}\text { A dummy variable that equals } 1 \text { if the IPO method is bookbuilding; } 0 \text { otherwise. } \\
\text { Source: Thomson One }\end{array}$ & 12125 & 0.71 & 0.45 & 0.00 & 1.00 \\
\hline LSIZE & Frim size: natural log of the total proceeds of the IPOs. Source: Thomson One & 12778 & 3.40 & 1.73 & -6.91 & 9.99 \\
\hline VOLUME & $\begin{array}{l}\text { IPO volume: for each country-year companion, it is the number of IPOs in a given } \\
\text { year in this country divided by the total number of IPOs throughout the sample period } \\
\text { in this country, expressed in } 100 \% \text {. Source: Thomson One. }\end{array}$ & 12778 & 9.71 & 6.96 & 0.10 & 100.00 \\
\hline MRETURN & $\begin{array}{l}\text { Market return: 3-month cumulative market return before the IPO date, based on the } \\
\text { market index in DataStream. Source: DataStream }\end{array}$ & 12778 & 3.82 & 9.61 & -40.46 & 80.16 \\
\hline TURNOVER & $\begin{array}{l}\text { Stock market turnover: annual turnover by value in the year of IPO. Source: } \\
\text { DataStream }\end{array}$ & 12471 & 981.54 & 630.41 & 4.17 & 4481 \\
\hline UNDERWRITER & $\begin{array}{l}\text { Global underwriter reputation: this is a widely-used measure of underwriters' } \\
\text { reputation following Megginson and Weiss (1991). Following Shi et al (2013), we } \\
\text { use the total proceeds underwritten by each lead underwriter as a share of the total } \\
\text { proceeds during our sample period. Source: Thomson One }\end{array}$ & 12364 & 1.22 & 2.43 & 0.00 & 8.99 \\
\hline$M I$ & $\begin{array}{l}\text { Market Integration: a measure of the actual market integration of one country with the } \\
\text { global markets by identifying the explanatory power of a multi-factor model on } \\
\text { global factors. R-squared is then used as an indicator of market integration. This } \\
\text { method is developed by Pukthuanthong and Roll (2009) with high frequency data. } \\
\text { For comparison purpose, it is presented in percentage levels in the estimations. } \\
\text { Source: DataStream }\end{array}$ & 12363 & 68.24 & 37.84 & 2.25 & 99.97 \\
\hline
\end{tabular}


Table 1: Variables description and descriptive statistics (continued)

\begin{tabular}{|c|c|c|c|c|c|c|}
\hline \multirow{2}{*}{ Variable } & \multirow{2}{*}{ Description } & \multicolumn{5}{|c|}{ Statistics } \\
\hline & & Obs & Mean & StD & Min & Max \\
\hline$I P I$ & $\begin{array}{l}\text { Investor Protection Index: measures the level of legal protection of minority } \\
\text { investors in one country; it ranges from } 0 \text { to } 10 \text { with higher values representing } \\
\text { better protection. For each company, the IPI of the country where it is firstly listed } \\
\text { has been included. This data is directly collected from the website of the Doing } \\
\text { Business project by the World Bank. }\end{array}$ & 12778 & 6.25 & 1.09 & 4.20 & 8.20 \\
\hline PEI & $\begin{array}{l}\text { Public Enforcement Index: measures the effectiveness of one country's legal } \\
\text { enforcement, i.e. court enforcement; it ranges from } 0 \text { to } 1 \text { with higher values } \\
\text { representing more effective legal enforcement (Djankov et al., 2008). For each } \\
\text { company, the } P E I \text { of the country where it is firstly listed has been included. This } \\
\text { data is directly collected from Rafael La Porta's website. }\end{array}$ & 12771 & 0.17 & 0.33 & 0.00 & 1.00 \\
\hline$R L I$ & $\begin{array}{l}\text { Rule of Law Index: measures the overall quality of the legal framework, with higher } \\
\text { values representing better legal system. This data is constructed by the World Justice } \\
\text { Project and collected from their website. For each company, the } R L I \text { of the country } \\
\text { where it is firstly listed has been included. }\end{array}$ & 11905 & 0.66 & 0.13 & 0.45 & 0.88 \\
\hline CPI & $\begin{array}{l}\text { Corruption Perception Index: measures the level of the overall corruption, with } 0 \\
\text { representing the most corrupted system. This data is constructed by the } \\
\text { Transparency International and collected from their website. For each company, the } \\
C P I \text { of the country where it is firstly listed has been included. }\end{array}$ & 12771 & 63.54 & 17.77 & 34.00 & 92.00 \\
\hline ENGLISH & $\begin{array}{l}\text { A dummy variable, which equals } 1 \text { if the country's legal system originates from the } \\
\text { English Common Law system. It is reported in La Porta et al. (1998). For each } \\
\text { company, the ENGLISH dummy is created of the country where it is firstly listed. }\end{array}$ & 12777 & 0.60 & 0.49 & 0 & 1 \\
\hline
\end{tabular}


Table 2: IPO underpricing by country

\begin{tabular}{|c|c|c|c|c|c|}
\hline Country & Mean & StD & $\mathbf{N}$ & Min & Max \\
\hline Argentina & 28.53 & 37.63 & 7.00 & 0.38 & 108.19 \\
\hline Australia & 18.46 & 38.37 & 960.00 & -50.19 & 402.86 \\
\hline Austria & 8.52 & 13.88 & 11.00 & -8.57 & 29.17 \\
\hline Belgium & 7.27 & 10.83 & 48.00 & -3.75 & 45.45 \\
\hline Brazil & 5.62 & 24.72 & 44.00 & -19.44 & 153.94 \\
\hline Canada & 22.73 & 39.72 & 332.00 & -25.64 & 219.32 \\
\hline China & 43.11 & 47.38 & 2729.00 & -39.44 & 705.00 \\
\hline Cyprus & 8.86 & 10.95 & 7.00 & 0.47 & 32.84 \\
\hline Denmark & 7.58 & 15.12 & 15.00 & -11.29 & 51.35 \\
\hline Finland & 7.10 & 22.33 & 16.00 & -26.71 & 80.72 \\
\hline France & 3.43 & 14.32 & 317.00 & -26.26 & 189.69 \\
\hline Germany & 24.40 & 109.71 & 87.00 & -18.57 & 890.00 \\
\hline Greece & 17.52 & 42.94 & 50.00 & -34.58 & 183.33 \\
\hline Hong Kong & 42.77 & 119.26 & 555.00 & -35.93 & 880.43 \\
\hline India & 14.89 & 31.38 & 188.00 & -29.14 & 213.82 \\
\hline Indonesia & 20.99 & 29.07 & 123.00 & -24.00 & 169.57 \\
\hline Israel & 17.46 & 29.00 & 91.00 & -27.50 & 113.33 \\
\hline Italy & 6.99 & 13.30 & 71.00 & -5.45 & 84.22 \\
\hline Japan & 39.77 & 50.80 & 550.00 & -30.56 & 353.55 \\
\hline Luxembourg & 6.57 & 10.18 & 16.00 & -13.60 & 25.40 \\
\hline Malaysia & 28.65 & 65.34 & 317.00 & -34.88 & 873.33 \\
\hline Mexico & 9.16 & 12.05 & 10.00 & -5.45 & 37.86 \\
\hline Netherlands & 7.33 & 23.09 & 46.00 & -19.50 & 137.19 \\
\hline New Zealand & 6.99 & 16.46 & 53.00 & -40.99 & 55.70 \\
\hline Norway & 2.33 & 8.70 & 62.00 & -23.19 & 40.30 \\
\hline Philippines & 10.16 & 19.51 & 35.00 & -17.44 & 50.27 \\
\hline Poland & 22.03 & 32.91 & 31.00 & -12.70 & 131.26 \\
\hline Singapore & 21.82 & 37.77 & 277.00 & -25.98 & 208.09 \\
\hline South Africa & 20.61 & 36.62 & 14.00 & -0.57 & 143.09 \\
\hline Spain & 4.35 & 8.23 & 13.00 & -5.10 & 19.10 \\
\hline Sweden & 21.10 & 45.96 & 48.00 & -45.58 & 230.00 \\
\hline Switzerland & 8.51 & 14.36 & 37.00 & -22.33 & 45.83 \\
\hline Taiwan & 24.37 & 34.82 & 722.00 & -24.28 & 233.36 \\
\hline Thailand & 33.16 & 48.51 & 264.00 & -42.42 & 198.18 \\
\hline Turkey & 7.26 & 11.84 & 9.00 & -4.66 & 31.03 \\
\hline United Kingdom & 14.10 & 25.23 & 668.00 & -58.33 & 276.09 \\
\hline United States & 24.01 & 41.22 & 3955.00 & -41.08 & 281.71 \\
\hline Total & 27.46 & 49.40 & 12778.00 & -58.33 & 890.00 \\
\hline
\end{tabular}

This table shows the summary statistics of the IPO underpricing by country. It contains the mean and standard deviation of IPO underpricing for each country, and the number of observations for each country in the sample of 12,778 IPOs from 1995 to 2017. It also presents the lowest and highest underpricing in every country during our sample period. 
Table 3: Summary statistics of country variables

Panel A: Measures of integration

\begin{tabular}{|c|c|c|c|c|c|c|}
\hline Country & $M I$ & $E G$ & $E G_{-} d f$ & $E G \_d j$ & Finance_df & Finance_dj \\
\hline Argentina & 0.144 & 42.49 & 37.80 & 47.18 & 57.81 & 49.02 \\
\hline Australia & 0.973 & 64.07 & 52.82 & 75.31 & 73.08 & 68.15 \\
\hline Austria & 0.901 & 80.14 & 75.46 & 84.81 & 85.74 & 77.89 \\
\hline Belgium & 0.848 & 79.98 & 80.42 & 79.19 & 84.51 & 75.44 \\
\hline Brazil & 0.380 & 46.18 & 36.45 & 55.91 & 50.14 & 54.25 \\
\hline Canada & 0.941 & 70.77 & 58.43 & 83.12 & 80.22 & 82.12 \\
\hline China & 0.052 & 43.98 & 49.23 & 38.74 & 51.22 & 15.61 \\
\hline Cyprus & 0.193 & 73.06 & 70.77 & 75.35 & 83.86 & 64.85 \\
\hline Denmark & 0.948 & 76.44 & 69.79 & 83.09 & 79.85 & 75.58 \\
\hline Finland & 0.505 & 75.78 & 67.03 & 84.54 & 81.26 & 77.15 \\
\hline France & 0.891 & 76.86 & 66.45 & 87.28 & 86.69 & 83.17 \\
\hline Germany & 0.839 & 78.87 & 73.11 & 84.64 & 84.41 & 78.38 \\
\hline Greece & 0.267 & 81.92 & 77.57 & 86.27 & 86.37 & 81.71 \\
\hline Hong Kong & 0.947 & 91.06 & 90.24 & 91.88 & 98.18 & 88.17 \\
\hline India & 0.130 & 56.44 & 53.92 & 58.96 & 54.92 & 50.53 \\
\hline Indonesia & 0.023 & 32.79 & 30.91 & 34.68 & 31.63 & 27.13 \\
\hline Israel & 0.220 & 69.10 & 56.66 & 81.54 & 69.11 & 77.00 \\
\hline Italy & 0.829 & 57.57 & 39.50 & 75.63 & 53.44 & 73.23 \\
\hline Japan & 0.993 & 84.14 & 80.59 & 87.82 & 90.38 & 82.53 \\
\hline Luxembourg & 0.295 & 51.89 & 40.39 & 63.32 & 51.82 & 61.96 \\
\hline Malaysia & 0.272 & 85.87 & 86.38 & 85.36 & 90.18 & 80.72 \\
\hline Mexico & 0.354 & 67.50 & 78.62 & 56.37 & 75.18 & 46.30 \\
\hline Netherlands & 0.891 & 75.23 & 70.02 & 80.43 & 80.22 & 77.03 \\
\hline New Zealand & 0.404 & 52.82 & 59.33 & 46.32 & 59.74 & 44.41 \\
\hline Norway & 0.594 & 70.93 & 63.23 & 78.62 & 77.28 & 75.70 \\
\hline Philippines & 0.171 & 60.99 & 59.02 & 62.96 & 62.67 & 48.60 \\
\hline Poland & 0.374 & 89.02 & 90.58 & 87.46 & 93.64 & 80.48 \\
\hline Singapore & 0.968 & 73.83 & 73.64 & 74.03 & 81.74 & 70.93 \\
\hline South Africa & 0.978 & 48.59 & 47.86 & 49.32 & 53.14 & 35.98 \\
\hline Spain & 0.736 & 76.05 & 67.50 & 84.60 & 81.68 & 77.03 \\
\hline Sweden & 0.660 & 56.42 & 59.78 & 53.06 & 54.27 & 42.83 \\
\hline Switzerland & 0.844 & 46.80 & 54.76 & 38.85 & 57.50 & 16.19 \\
\hline Taiwan & 0.170 & 56.09 & 45.54 & 66.65 & 62.37 & 56.62 \\
\hline Thailand & 0.246 & 51.01 & 42.10 & 59.93 & 44.11 & 47.69 \\
\hline Turkey & 0.150 & 61.15 & 38.47 & 83.82 & 57.77 & 80.55 \\
\hline United Kingdom & 0.850 & 82.91 & 79.00 & 86.82 & 87.75 & 82.30 \\
\hline United States & 0.947 & 50.94 & 55.06 & 46.82 & 61.44 & 31.32 \\
\hline
\end{tabular}

This table presents the mean value of different measures of the integration for each country across the 1995-2017 sample period. The variable of interest is $M I$ which measures the actual market integration and is constructed following Pukthuanthong and Roll (2009). The other five measures are constructed by the KOF Swiss Economic Institute. EG is the overall economic globalization which takes the average of the de-facto $\left(E G \_d f\right)$ and de-jure $\left(E G \_d j\right)$ economic globalization measures. We also include two sub-indices, one de-facto (Finance_df) and one de-jure (Finance dj), that are used in the construction of $E G$ to capture the financial market integration. 
Panel B: Country institutional variables

\begin{tabular}{lccccc}
\hline \hline Country & IPI & PEI & RLI & CPI & ENGLISH \\
\hline Argentina & 5.80 & 0.00 & 0.50 & 34.00 & 0 \\
Australia & 5.70 & 0.50 & 0.80 & 80.00 & 1 \\
Austria & 6.30 & 1.00 & 0.82 & 72.00 & 0 \\
Belgium & 6.20 & 0.50 & 0.76 & 76.00 & 0 \\
Brazil & 6.30 & 0.50 & 0.54 & 43.00 & 0 \\
Canada & 7.30 & 1.00 & 0.78 & 81.00 & 1 \\
China & 4.50 & 0.00 & 0.45 & 36.00 & 0 \\
Cyprus & 6.80 & $/$ & $/$ & $/$ & 0 \\
Denmark & 6.80 & 0.75 & 0.88 & 92.00 & 0 \\
Finland & 5.60 & 0.00 & 0.84 & 89.00 & 0 \\
France & 6.80 & 0.50 & 0.74 & 69.00 & 0 \\
Germany & 5.90 & 1.00 & 0.80 & 79.00 & 0 \\
Greece & 5.80 & 0.50 & 0.59 & 43.00 & 0 \\
Hong Kong & 8.10 & 0.00 & 0.76 & 74.00 & 1 \\
India & 7.30 & 0.50 & 0.48 & 38.00 & 1 \\
Indonesia & 6.10 & 0.00 & 0.52 & 34.00 & 0 \\
Israel & 7.10 & 1.00 & $/$ & 60.00 & 1 \\
Italy & 6.70 & 0.00 & 0.63 & 43.00 & 0 \\
Japan & 6.30 & 0.00 & 0.78 & 76.00 & 0 \\
Luxembourg & 4.70 & 1.00 & $/$ & 82.00 & 0 \\
Malaysia & 7.40 & 1.00 & 0.58 & 52.00 & 1 \\
Mexico & 5.80 & 0.50 & 0.45 & 35.00 & 0 \\
Netherlands & 5.20 & 0.00 & 0.83 & 83.00 & 0 \\
New Zealand & 8.20 & 0.00 & 0.83 & 91.00 & 1 \\
Norway & 7.00 & 1.00 & 0.88 & 86.00 & 0 \\
Philippines & 4.20 & 0.00 & 0.50 & 38.00 & 0 \\
Poland & 6.30 & 1.00 & 0.67 & 61.00 & 0 \\
Singapore & 8.00 & 1.00 & 0.79 & 84.00 & 1 \\
South Africa & 6.80 & 0.00 & 0.55 & 44.00 & 1 \\
Spain & 6.40 & 1.00 & 0.67 & 60.00 & 0 \\
Sweden & 6.30 & 1.00 & 0.85 & 87.00 & 0 \\
Switzerland & 5.50 & 0.75 & $/$ & 86.00 & 0 \\
Taiwan & 6.40 & 0.00 & $/$ & 61.00 & 0 \\
Thailand & 6.60 & 0.00 & 0.52 & 38.00 & 1 \\
Turkey & 6.90 & 0.00 & 0.50 & 45.00 & 0 \\
United Kingdom & 7.80 & 0.00 & 0.78 & 78.00 & 1 \\
United States & 6.60 & 0.00 & 0.71 & 74.00 & 1 \\
\hline Mean & 6.35 & 0.43 & 0.66 & 61.71 & 0.31 \\
\hline \hline Ths & 5.00 & 0 \\
\hline
\end{tabular}

This table presents each country's institutional variables. All the variables are held constant for each country throughout the sample period from 1995 to 2017. Investor Protection Index (IPI) measures the level of the legal protection of minority investors in one country, with higher values representing better protection. Public Enforcement Index (PEI) measures the effectiveness of the legal enforcement, with higher values representing more effective legal enforcement. Rule of Law Index (RLI) measures the overall quality of the legal framework, with higher values representing better legal system. Corruption Perception Index (CPI) measures the level of the overall corruption, with 0 representing the most corrupted system. ENGLISH is a dummy variable, which equals 1 if the country's legal system originates from the English Common Law. 
Table 4: Direct effect of market integration on IPO underpricing (HLM)

\begin{tabular}{|c|c|c|c|c|c|}
\hline \multirow{2}{*}{$\begin{array}{l}\text { Dependent Variable } \\
\text { Underpricing }\end{array}$} & \multicolumn{5}{|c|}{ Hierarchical Linear Modelling } \\
\hline & $(1)$ & $(2)$ & (3) & $(4)$ & $(5)$ \\
\hline \multirow{3}{*}{$V B$} & MI & $E G \_d f$ & $E G_{Z} d j$ & $F G \_d f$ & $\overline{F G \_d j}$ \\
\hline & $4.459 * * *$ & $6.041^{* * *}$ & $6.21 \overline{5} * * *$ & $6.28 \overline{6} * * *$ & $6.215 * * *$ \\
\hline & 1.113 & 1.105 & 1.104 & 1.101 & 1.101 \\
\hline \multirow[t]{2}{*}{$B B$} & $-9.014 * * *$ & $-19.65 * * *$ & $-16.89 * * *$ & $-19.18 * * *$ & $-16.11 * * *$ \\
\hline & 1.415 & 1.636 & 1.621 & 1.611 & 1.621 \\
\hline \multirow[t]{2}{*}{ LSIZE } & $-3.670 * * *$ & $-2.333 * * *$ & $-2.652 * * *$ & $-2.372 * * *$ & $-2.853 * * *$ \\
\hline & 0.357 & 0.355 & 0.358 & 0.354 & 0.358 \\
\hline \multirow[t]{2}{*}{ VOLUME } & $-0.480 * * *$ & $-0.412 * * *$ & $-0.440 * * *$ & $-0.473 * * *$ & $-0.349 * * *$ \\
\hline & 0.075 & 0.091 & 0.091 & 0.091 & 0.091 \\
\hline \multirow[t]{2}{*}{ MRETURN } & $0.395 * * *$ & $0.406^{* * *}$ & $0.433 * * *$ & $0.428 * * *$ & $0.448 * * *$ \\
\hline & 0.045 & 0.045 & 0.045 & 0.045 & 0.045 \\
\hline \multirow[t]{2}{*}{ TURNOVER } & $-0.005 * * *$ & $-0.008 * * *$ & $-0.012 * * *$ & $-0.004 * * *$ & $-0.014 * * *$ \\
\hline & 0.001 & 0.001 & 0.001 & 0.001 & 0.001 \\
\hline \multirow[t]{2}{*}{ UNDERWRITER } & $1.715 * * *$ & $1.783 * * *$ & $1.955 * * *$ & $1.928 * * *$ & $2.015 * * *$ \\
\hline & 0.219 & 0.210 & 0.211 & 0.210 & 0.210 \\
\hline \multirow[t]{2}{*}{ INTEGRATION } & $-0.358 * * *$ & $-0.331 * * *$ & $-0.496 * * *$ & $-0.448 * * *$ & $-0.494 * * *$ \\
\hline & 0.024 & 0.052 & 0.063 & 0.045 & 0.047 \\
\hline \multirow[t]{2}{*}{ Constant } & $65.59 * * *$ & $64.44 * * *$ & $82.97 * * *$ & $75.18 * * *$ & $79.37 * * *$ \\
\hline & 3.682 & 4.241 & 5.776 & 4.153 & 4.593 \\
\hline \multirow[t]{2}{*}{$\operatorname{var}($ c.country $)$} & $187.0 * * *$ & $101.7 * * *$ & $136.2 * * *$ & $88.72 * * *$ & $145.3 * * *$ \\
\hline & 52.56 & 29.67 & 39.87 & 27.44 & 42.38 \\
\hline \multirow{2}{*}{$\operatorname{var}(e . i r)$} & $2,144 * * *$ & $1,681 * * *$ & $1,675^{* * *}$ & $1,671 * * *$ & $1,665 * * *$ \\
\hline & 28.97 & 26.26 & 26.16 & 26.09 & 26.00 \\
\hline Observations & 10,991 & 8,228 & 8,228 & 8,228 & 8,228 \\
\hline Number of groups & 37 & 37 & 37 & 37 & 37 \\
\hline
\end{tabular}

This table presents the regression results of the IPO underpricing from 1995 to 2017, by multi-level modelling. IPO underpricing is firstly modelled at firm level and then at country level. A random intercept model is assumed with the intercept shifting between countries due to the random country effect. Models (1) to (5) present the results using different measures of integration (INTEGRATION). The baseline model is Model (1) which uses a de facto measure of stock market integration $(M I) . M I$ is the R-squared of the regression of a country's daily market performance in a given year on the global factors, a method developed by Pukthuanthong and Roll (2009). Model (1) uses a sample of 10,991 observations from 37 countries. For the efficiency of the calculation, we choose countries which have a minimum number of IPOs equal or larger than 6. Models (2) to (5) use alternative measures of globalization and integration that are constructed by the KOF Swiss Economic Institute. Model (2) adopts a de facto measure of economic globalization $\left(E G \_d f\right)$ which captures both the exchange of trade, capital flows and stocks of foreign assets and liabilities. Model (3) adopts a de jure measure of economic globalization $(E G d j)$ which focuses on policies on trade and capital flows. Models (4) and (5) adopt financial integration measures which are closer to our market integration measure. Finance $d f$ is the de facto measure which is the sum of external assets and liabilities as a share of GDP, a method firstly developed by Lane and Milesi-Ferretti (2003) and revised in Lane and Milesi-Ferretti (2007). Finance_dj measures the country's capital account openness based on its restrictions on the cross-border financial transactions, a measure developed by Chinn and Ito (2006). The dependent variable is Underpricing which is the initial return between the first-trading day closing price and the IPO offer price, expressed as a percentage. $V B$ captures the venture-backed status of the IPO firm and equals 1 if the IPO is venture capital-backed. $B B$ is a dummy variable and equals 1 if the IPO uses book-building as an issuing technique. LSIZE is the offer size of the IPO, expressed in logarithm. VOLUME, for each country-year companion, is the number of IPOs in a certain year in one country divided by the total number of IPOs throughout the sample period in this country. MRETURN is the 3-month cumulative market return before the IPO, based on the country market index in DataStream. TURNOVER is the stock turnover by value recorded in DataStream which is the value of the shares traded divided by the average market capitalization. UNDERWRITER is the underwriter's reputation which is measured by the IPO market share of this underwriter during the 1995-2017 sample period. var(c.country) is the variance between countries and var(e.ir) is the variance between individual IPOs. The figures below each coefficient are the standard errors. Significance at $10 \%, 5 \%$ and $1 \%$ levels are marked with *, **, and $* * *$ respectively. 
Table 5: Direct effect of market integration on IPO underpricing (OLS)

\begin{tabular}{|c|c|c|c|c|c|}
\hline \multirow{2}{*}{$\begin{array}{l}\text { Dependent Variable } \\
\text { Underpricing }\end{array}$} & \multicolumn{5}{|c|}{ OLS } \\
\hline & $(1)$ & $(2)$ & (3) & (4) & $(5)$ \\
\hline \multirow{3}{*}{$V B$} & $M I$ & $E G \_d f$ & $\overline{E G \_d j}$ & $F G \_d f$ & $F G_{Z} d j$ \\
\hline & $9.356 * * *$ & $7.551^{* * *}$ & $9.883 * * *$ & $7.21 \overline{2} * * *$ & $10.14 * * *$ \\
\hline & 0.959 & 1.069 & 1.068 & 1.063 & 1.066 \\
\hline \multirow[t]{2}{*}{$B B$} & -1.632 & $-16.77 * * *$ & $-4.636 * * *$ & $-17.89 * * *$ & $-3.261 * * *$ \\
\hline & 1.352 & 1.528 & 1.267 & 1.433 & 1.255 \\
\hline \multirow[t]{2}{*}{ LSIZE } & $-2.271 * * *$ & -0.381 & $-1.829 * * *$ & $-1.357 * * *$ & $-2.039 * * *$ \\
\hline & 0.305 & 0.332 & 0.339 & 0.331 & 0.337 \\
\hline \multirow[t]{2}{*}{ VOLUME } & $-0.536 * * *$ & $-0.578 * * *$ & $-0.540 * * *$ & $-0.534 * * *$ & $-0.467 * * *$ \\
\hline & 0.058 & 0.091 & 0.088 & 0.090 & 0.087 \\
\hline \multirow[t]{2}{*}{ MRETURN } & $0.425 * * *$ & $0.488 * * *$ & $0.498 * * *$ & $0.473 * * *$ & $0.504 * * *$ \\
\hline & 0.051 & 0.057 & 0.055 & 0.054 & 0.055 \\
\hline \multirow[t]{2}{*}{ TURNOVER } & $-0.002 * * *$ & -0.001 & $-0.004 * * *$ & $0.003 * * *$ & $-0.005 * * *$ \\
\hline & 0.001 & 0.001 & 0.001 & 0.001 & 0.001 \\
\hline \multirow[t]{2}{*}{ UNDERWRITER } & $1.141 * * *$ & $0.677 * * *$ & $1.650 * * *$ & $1.273 * * *$ & $1.733 * * *$ \\
\hline & 0.223 & 0.247 & 0.255 & 0.248 & 0.255 \\
\hline \multirow[t]{2}{*}{ INTEGRATION } & $-0.235 * * *$ & $-0.430 * * *$ & $-0.548 * * *$ & $-0.658 * * *$ & $-0.425 * * *$ \\
\hline & 0.013 & 0.031 & 0.030 & 0.031 & 0.022 \\
\hline \multirow[t]{2}{*}{ Constant } & $54.01 * * *$ & $64.04 * * *$ & $78.48 * * *$ & $84.09 * * *$ & $66.05 * * *$ \\
\hline & 1.926 & 2.998 & 3.304 & 3.269 & 2.635 \\
\hline Observations & 10,991 & 8,228 & 8,228 & 8,228 & 8,228 \\
\hline$R$-squared & 0.045 & 0.056 & 0.079 & 0.092 & 0.084 \\
\hline
\end{tabular}

This table presents the OLS regression results of the IPO underpricing from 1995 to 2017. Models (1) to (5) present the results using different measures of integration (INTEGRATION). Model (1) which uses our variable of interest which is a de facto measurement of stock market integration $(M I)$. $M I$ is the R-squared of the regression of a country's daily market performance in a given year on the global factors, a method developed by Pukthuanthong and Roll (2009). Model (1) uses a sample of 10,991 observations from 37 countries. For the efficiency of the calculation, we choose countries which have a minimum number of IPOs equal or larger than 6. Models (2) to (5) use alternative measures of globalization and financial market integration that are constructed by the KOF Swiss Economic Institute. Model (2) adopts a de facto measure of economic globalization $\left(E G \_f f\right)$ which captures both the exchange of trade, capital flows and stocks of foreign assets and liabilities. Model (3) adopts a de jure measure of economic globalization ( $E G \_d j$ ) which focuses on policies on trade and capital flows. Models (4) and (5) adopt financial integration measures which are closer to our market integration measure. Finance $d f$ is the de facto measure which is the sum of external assets and liabilities as a share of GDP, a method firstly developed by Lane and Milesi-Ferretti (2003) and revised in Lane and Milesi-Ferretti (2007). Finance dj measures the country's capital account openness based on its restrictions on the cross-border financial transactions, a measure developed by Chinn and Ito (2006). The dependent variable is Underpricing which is the initial return between the first-trading day closing price and the IPO offer price, expressed as a percentage. $V B$ captures the venture-backed status of the IPO firm and equals 1 if the IPO is venture capital-backed. $B B$ is a dummy variable and equals 1 if the IPO uses book-building as an issuing technique. LSIZE is the offer size of the IPO, expressed in logarithm. VOLUME, for each country-year companion, is the number of IPOs in a certain year in one country divided by the total number of IPOs throughout the sample period in this country. MRETURN is the 3-month cumulative market return before the IPO, based on the country market index in DataStream. TURNOVER is the stock turnover by value recorded in DataStream which is the value of the shares traded divided by the average market capitalization. UNDERWRITER is the underwriter's reputation which is measured by the IPO market share of this underwriter during the 1995-2017 sample period. The figures below each coefficient are the standard errors. Significance at $10 \%, 5 \%$ and $1 \%$ levels are marked with $*, * *$, and $* * *$ respectively. 
Table 6 Propensity score matching results (Logit Model)

Outcome variable:
Underpricing


Table 7: Indirect effect of market integration on IPO underpricing

\begin{tabular}{|c|c|c|c|c|c|}
\hline \multirow{2}{*}{$\begin{array}{l}\text { Dependent Variable: } \\
\text { Underpricing }\end{array}$} & \multicolumn{5}{|c|}{ Hierarchical Linear Modelling } \\
\hline & (1) & (2) & (3) & (4) & $(5)$ \\
\hline & IPI & PEI & RLI & $C P I$ & ENGLISH \\
\hline$V B$ & $\begin{array}{l}4.216^{* * *} \\
1.113\end{array}$ & $\begin{array}{l}4.201 * * * \\
1.112\end{array}$ & $\begin{array}{l}4.309 * * * \\
1.141\end{array}$ & $\begin{array}{l}4.359 * * * \\
1.113\end{array}$ & $\begin{array}{c}4.407 * * * \\
1.114\end{array}$ \\
\hline$B B$ & $-9.023 * * *$ & $-9.374 * * *$ & $-10.93 * * *$ & $-8.595 * * *$ & $-9.132 * * *$ \\
\hline & 1.407 & 1.438 & 1.587 & 1.425 & 1.414 \\
\hline LSIZE & $\begin{array}{c}-3.860 * * * \\
0.355\end{array}$ & $\begin{array}{c}-3.732 * * * \\
0.356\end{array}$ & $\begin{array}{l}-3.754 * * * \\
0.37\end{array}$ & $\begin{array}{c}-3.726^{* * *} \\
0.357\end{array}$ & $\begin{array}{c}-3.734 * * * \\
0.357\end{array}$ \\
\hline VOLUME & $\begin{array}{c}-0.440 * * * \\
0.075\end{array}$ & $\begin{array}{c}-0.460 * * * \\
0.076\end{array}$ & $\begin{array}{c}-0.421 * * * \\
0.078\end{array}$ & $\begin{array}{c}-0.465 * * * \\
0.076\end{array}$ & $\begin{array}{c}-0.450 * * * \\
0.076\end{array}$ \\
\hline MRETURN & $\begin{array}{l}0.401 * * * \\
0.045\end{array}$ & $\begin{array}{l}0.397 * * * \\
0.045\end{array}$ & $\begin{array}{c}0.406^{* * *} \\
0.048\end{array}$ & $\begin{array}{c}0.395^{* * *} \\
0.045\end{array}$ & $\begin{array}{c}0.397 * * * \\
0.045\end{array}$ \\
\hline TURNOVER & $\begin{array}{c}-0.006^{* * *} \\
0.001\end{array}$ & $\begin{array}{c}-0.006^{* * *} \\
0.001\end{array}$ & $\begin{array}{c}-0.005 * * * \\
0.001\end{array}$ & $\begin{array}{c}-0.006^{* * *} \\
0.001\end{array}$ & $\begin{array}{c}-0.006^{* * *} \\
0.001\end{array}$ \\
\hline UNDERWRITER & $\begin{array}{l}1.776^{* * *} \\
0.219\end{array}$ & $\begin{array}{l}1.762 * * * \\
0.219\end{array}$ & $\begin{array}{l}1.778 * * * \\
0.224\end{array}$ & $\begin{array}{l}1.730 * * * \\
0.219\end{array}$ & $\begin{array}{l}1.720 * * * \\
0.219\end{array}$ \\
\hline MI & $\begin{array}{c}-1.467 * * * \\
0.200\end{array}$ & $\begin{array}{c}-0.391 * * * \\
0.026\end{array}$ & $\begin{array}{c}-1.154 * * * \\
0.321\end{array}$ & $\begin{array}{c}-0.936^{* * *} \\
0.204\end{array}$ & $\begin{array}{c}-0.430 * * * \\
0.059\end{array}$ \\
\hline Institution & $\begin{array}{l}-16.71 * * * \\
2.080\end{array}$ & $\begin{array}{l}-51.96^{* * *} \\
8.301\end{array}$ & $\begin{array}{l}-88.84 * * * \\
27.400\end{array}$ & $\begin{array}{c}-0.580 * * * \\
0.175\end{array}$ & $\begin{array}{c}-22.94 * * * \\
6.209\end{array}$ \\
\hline MI x Institution & $\begin{array}{c}0.206^{* * *} \\
0.032\end{array}$ & $\begin{array}{c}0.522 * * * \\
0.096\end{array}$ & $\begin{array}{c}1.380^{* * *} \\
0.487\end{array}$ & $\begin{array}{c}0.0103 * * * \\
0.003\end{array}$ & $\begin{array}{c}0.282 * * * \\
0.089\end{array}$ \\
\hline Constant & $\begin{array}{c}158.4 * * * \\
12.23\end{array}$ & $\begin{array}{c}73.74 * * * \\
4.001\end{array}$ & $\begin{array}{c}112.9^{* * *} \\
14.60\end{array}$ & $\begin{array}{c}92.33^{* * *} * \\
8.650\end{array}$ & $\begin{array}{c}71.29 * * * \\
4.162\end{array}$ \\
\hline $\operatorname{var}($ c.country) & $\begin{array}{c}102.4 * * * \\
32.66\end{array}$ & $\begin{array}{c}204.7 * * * \\
60.12\end{array}$ & $\begin{array}{c}154.5^{* * *} \\
45.96\end{array}$ & $\begin{array}{c}166.2 * * * \\
47.83\end{array}$ & $\begin{array}{c}171.7^{* * *} \\
49.98\end{array}$ \\
\hline $\operatorname{var}(e . i r)$ & $\begin{array}{c}2,136^{* * *} \\
28.85\end{array}$ & $\begin{array}{c}2,135^{* * * *} \\
28.85\end{array}$ & $\begin{array}{c}2,200 * * * \\
30.64\end{array}$ & $\begin{array}{c}2,142^{* * *} \\
28.94\end{array}$ & $\begin{array}{c}2,142 * * * \\
28.94\end{array}$ \\
\hline Observations & 10,991 & 10,991 & 10,337 & 10,991 & 10,991 \\
\hline Number of groups & 37 & 37 & 37 & 37 & 37 \\
\hline
\end{tabular}

This table presents the regression results of the IPO underpricing from 1995 to 2017 by multi-level modelling. IPO underpricing is firstly modelled at firm level and then at country level. A random intercept model assumes that the intercept shifts between countries due to the random country effect. Models (1) to (5) present the results including five different country-level institutional variables respectively. The dependent variable is Underpricing which is the initial return between the first-trading day closing price and the IPO offer price, expressed as a percentage. $V B$ captures the venture-backed status of the IPO firm and equal to 1 if the IPO is venture capital-backed. $B B$ is a dummy variable and equals to 1 if the IPO uses book-building as an issuing technique. LSIZE is the offer size of the IPO, expressed in a logarithm. VOLUME, for each country-year companion, is the number of IPOs in a certain year in one country divided by the total number of IPOs throughout the sample period in this country. MRETURN is the 3-month cumulative market return before the IPO, based on the country market index in DataStream. TURNOVER is the stock turnover by value recorded in DataStream which is the value of the shares traded divided by the average market capitalization. UNDERWRITER is the underwriter's reputation which is measured by the IPO market share of this underwriter during 1995-2017. Market integration (MI) is the R-squared of the regression of a country's daily market performance in a given year on the global factors, a method developed by Pukthuanthong and Roll (2009). Institution represents each of the five country-level institutional variables from Models (1) to (5). IPI is the Investor Protection Index, which measures the level of legal protection of minority investors in one country; it ranges from 0 to 10 with higher values representing better protection. PEI is the Public Enforcement Index, which 
measures the effectiveness of one country's legal enforcement, i.e. court enforcement; it ranges from 0 to 1 with higher values representing more effective legal enforcement. $R L I$ is the Rule of Law Index, which measures the overall quality of the legal framework; it ranges from 0 to 100 with higher values representing a better legal system. $C P I$ is the Corruption Perception Index, which measures the level of the overall corruption; it ranges from 0 to 100 with 0 representing the most corrupted system. ENGLISH is a dummy variable which equals 1 if the country's legal system originates from the English Common Law and 0 otherwise. The variable of interest here is MI $x$ Institution, which is the interaction term between each of these institutional variables and MI, i.e. MI x Institution in Model (1) is equal to MI* IPI. var(c.country) is the variance between countries and $\operatorname{var}($ e.ir) is the variance between individual IPOs. The figures below each coefficient are the standard errors. Significance at $10 \%, 5 \%$ and $1 \%$ levels are marked with *, $* *$, and $* * *$ respectively. 
Table 8: Robustness - Constant low/high value of market integration

\begin{tabular}{|c|c|c|c|c|c|c|c|c|}
\hline \multirow{2}{*}{$\begin{array}{l}\text { Dependent Variable } \\
\text { Underpricing }\end{array}$} & \multicolumn{8}{|c|}{ "Hierarchical Linear Modelling } \\
\hline & (1a) & (1b) & $(2 a)$ & $(2 b)$ & (3a) & $(3 b)$ & $(4 a)$ & (4b) \\
\hline \multirow{3}{*}{ MI_Low } & Low & High & Low & High & Low & High & Low & High \\
\hline & $-1.467 * * *$ & & $-0.391 * * *$ & & $-1.154 * * *$ & & $-0.936^{* * *}$ & \\
\hline & -0.200 & & -0.026 & & -0.321 & & -0.204 & \\
\hline \multirow[t]{2}{*}{ MI_High } & & $-1.467 * * *$ & & $-0.391 * * *$ & & $-1.154 * * *$ & & $-0.936 * * *$ \\
\hline & & -0.200 & & -0.026 & & -0.321 & & -0.204 \\
\hline \multirow[t]{2}{*}{ Institution } & $-10.44 * * *$ & $-5.154 * * *$ & $-36.10 * * *$ & 3.379 & $-46.87 * *$ & 57.56 & $-0.266 * *$ & $0.516^{* *}$ \\
\hline & 1.359 & 1.945 & 5.675 & 3.760 & 19.28 & 36.43 & 0.129 & 0.245 \\
\hline \multirow[t]{2}{*}{ Interaction_Low } & $0.206 * * *$ & & $0.522 * * *$ & & $1.380 * * *$ & & $0.0103 * * *$ & \\
\hline & 0.032 & & 0.096 & & 0.487 & & 0.003 & \\
\hline \multirow[t]{2}{*}{ Interaction_High } & & $0.206^{* * *}$ & & $0.522 * * *$ & & $1.380 * * *$ & & $0.0103 * * *$ \\
\hline & & 0.032 & & 0.096 & & 0.487 & & 0.003 \\
\hline \multirow[t]{2}{*}{ Constant } & $113.8 * * *$ & 2.733 & $61.87 * * *$ & $32.31 * * *$ & $77.83 * * *$ & -9.503 & $63.86 * * *$ & -7.005 \\
\hline & 8.298 & 13.76 & 3.661 & 3.487 & 11.38 & -27.38 & 7.495 & -18.55 \\
\hline \multirow[t]{2}{*}{$\operatorname{var}($ c.country) } & $102.4 * * *$ & $102.4 * * *$ & $204.7 * * *$ & $204.7 * * *$ & $154.5 * * *$ & $154.5 * * *$ & $166.2 * * *$ & $166.2 * * *$ \\
\hline & 32.66 & 32.66 & 60.12 & 60.12 & 45.96 & 45.96 & 47.83 & 47.83 \\
\hline \multirow[t]{2}{*}{$\operatorname{var}(e . i r)$} & $2,136 * * *$ & $2,136^{* * *}$ & $2,135 * * *$ & $2,135 * * *$ & $2,200 * * *$ & $2,200 * * *$ & $2,142 * * *$ & $2,142 * * *$ \\
\hline & 28.85 & 28.85 & 28.85 & 28.85 & 30.64 & 30.64 & 28.94 & 28.94 \\
\hline Control Variables & Yes & Yes & Yes & Yes & Yes & Yes & Yes & Yes \\
\hline Observations & 10,991 & 10,991 & 10,991 & 10,991 & 10,337 & 10,337 & 10,991 & 10,991 \\
\hline Number of groups & 37 & 37 & 37 & 37 & 37 & 37 & 37 & 37 \\
\hline
\end{tabular}

This table presents the regression results of the IPO underpricing from 1995 to 2017, by multi-level modelling, when the moderator variable—-market integration (MI)—is held constant at low and high values for each institutional variable. IPO underpricing is firstly modelled at firm level and then at country level. A random intercept model assumes that the intercept shifts between countries due to the random country effect. Models (1) to (4) present the results including four continuous country-level institutional variables respectively. The dependent variable is Underpricing which is the initial return between the first-trading day closing price and the IPO offer price, expressed as a percentage. While results are not reported here, control variables are also included: $V B$ captures the venture-backed status of the IPO firm and equals 1 if the IPO is venture capital-backed. $B B$ is a dummy variable and equals 1 if the IPO uses book-building as an issuing technique. LSIZE is the offer size of the IPO, expressed in logarithm. VOLUME, for each country-year companion, is the number of IPOs in a certain year in one country divided by the 
total number of IPOs throughout the sample period in this country. MRETURN is the 3-month cumulative market return before the IPO, based on the country market index in DataStream. TURNOVER is the stock turnover by value recorded in DataStream which is the value of the shares traded divided by the average market capitalization. UNDERWRITER is the underwriter's reputation which is measured by the IPO market share of this underwriter during the 1995-2017 sample period. Under each model, there are two models - (a) and (b) - where MI is held constant at low (MI_Low) and high (MI_High) values. MI_Low is the market integration held constant at 1 standard deviation below the mean, and MI_High is the market integration held constant at 1 standard deviation above the mean. Market integration $(M I)$ is the R-squared of the regression of a country's daily market performance in a given year on global factors, a method developed by Pukthuanthong and Roll (2009). Institution represents each of the four country-level institutional variables from Models (1) to (4). IPI is the Investor Protection Index, which measures the level of the legal protection of minority investors in one country; it ranges from 0 to 10 with higher values representing better protection. PEI is the Public Enforcement Index, which measures the effectiveness of one country's legal enforcement, i.e. court enforcement; it ranges from 0 to 1 with higher values representing more effective legal enforcement. RLI is the Rule of Law Index, which measures the overall quality of the legal framework; it ranges from 0 to 100 with higher values representing better legal system. $C P I$ is the Corruption Perception Index, which measures

the level of the overall corruption; it ranges from 0 to 100 with 0 representing the most corrupted system. Interaction Low and Interaction High are the interaction term between each institutional variable and respectively MI Low and MI_High; i.e. Interaction_Low in Model (1a) is equal to MI_Low * IPI. var(c.country) is the variance between countries and var(e.ir) is the variance between individual IPOs. The statistics shown under each coefficient are the standard errors. Significance at $10 \%, 5 \%$ and $1 \%$ levels are marked with $*, * *$, and $* * *$ respectively. 
Table 9: Robustness - Indirect effect with alternative measure of integration

\begin{tabular}{|c|c|c|c|c|c|}
\hline \multirow{2}{*}{$\begin{array}{l}\text { Dependent Variable } \\
\text { Underpricing }\end{array}$} & \multicolumn{5}{|c|}{ Hierarchical Linear Modelling } \\
\hline & (1) & (2) & (3) & (4) & $(5)$ \\
\hline & $I P I$ & $P E I$ & $R L I$ & $C P I$ & ENGLISH \\
\hline \multirow[t]{2}{*}{$V B$} & $5.908 * * *$ & $6.104 * * *$ & $6.021 * * *$ & $6.100 * * *$ & $5.962 * * *$ \\
\hline & 1.101 & 1.102 & 1.103 & 1.1 & 1.1 \\
\hline \multirow[t]{2}{*}{$B B$} & $-16.92 * * *$ & $-19.74 * * *$ & $-16.80 * * *$ & $-16.67 * * *$ & $-16.68 * * *$ \\
\hline & 1.619 & 1.640 & 1.634 & 1.637 & 1.625 \\
\hline \multirow[t]{2}{*}{$L S I Z E$} & $-2.795 * * *$ & $-2.554 * * *$ & $-2.812 * * *$ & $-2.766^{* * *}$ & $-2.768 * * *$ \\
\hline & 0.356 & 0.354 & 0.357 & 0.357 & 0.356 \\
\hline \multirow[t]{2}{*}{ VOLUME } & $-0.480 * * *$ & $-0.420 * * *$ & $-0.502 * * *$ & $-0.517 * * *$ & $-0.501 * * *$ \\
\hline & 0.091 & 0.092 & 0.093 & 0.092 & 0.092 \\
\hline \multirow[t]{2}{*}{ MRETURN } & $0.435 * * *$ & $0.421 * * *$ & $0.435 * * *$ & $0.434 * * *$ & $0.437 * * *$ \\
\hline & 0.045 & 0.045 & 0.045 & 0.045 & 0.045 \\
\hline \multirow[t]{2}{*}{ TURNOVER } & $-0.012 * * *$ & $-0.009 * * *$ & $-0.013 * * *$ & $-0.013 * * *$ & $-0.013 * * *$ \\
\hline & 0.001 & 0.001 & 0.001 & 0.001 & 0.001 \\
\hline \multirow[t]{2}{*}{ UNDERWRITER } & $2.071 * * *$ & $1.928 * * *$ & $2.094 * * *$ & $2.096 * * *$ & $2.073 * * *$ \\
\hline & 0.211 & 0.211 & 0.212 & 0.211 & 0.211 \\
\hline \multirow[t]{2}{*}{$E G$} & $-2.399 * * *$ & $-0.784 * * *$ & $-1.264 * *$ & $-1.394 * * *$ & $-0.874 * * *$ \\
\hline & 0.431 & 0.097 & 0.589 & 0.393 & 0.120 \\
\hline \multirow[t]{2}{*}{ Institution } & $-33.56 * * *$ & $-94.26 * * *$ & $-284.1 * * *$ & $-1.977 * * *$ & $-79.72 * * *$ \\
\hline & 4.341 & 16.81 & 42.26 & 0.304 & 11.63 \\
\hline \multirow[t]{2}{*}{ EG $x$ Institution } & $0.374 * * *$ & $1.200 * * *$ & $2.403 * * *$ & $0.022 * * *$ & $1.020 * * *$ \\
\hline & 0.064 & 0.224 & 0.767 & 0.005 & 0.177 \\
\hline \multirow[t]{2}{*}{ Constant } & $262.1 * * *$ & $100.5^{* * *}$ & $215.6^{* * *}$ & $171.5 * * *$ & $111.9 * * *$ \\
\hline & 26.54 & 6.791 & 28.10 & 20.02 & 8.053 \\
\hline \multirow[t]{2}{*}{$\operatorname{var}($ c.country) } & $106.5 * * *$ & $78.34 * * *$ & $230.8 * * *$ & $193.1 * * *$ & $108.8^{* * *}$ \\
\hline & 35.95 & 26.41 & 73.23 & 59.58 & 36.10 \\
\hline \multirow[t]{2}{*}{$\operatorname{var}(e . i r)$} & $1,660 * * *$ & $1,671 * * *$ & $1,660 * * *$ & $1,660 * * *$ & $1,663 * * *$ \\
\hline & 25.94 & 26.1 & 25.98 & 25.94 & 25.98 \\
\hline Observations & 8,228 & 8,228 & 8,206 & 8,228 & 8,228 \\
\hline Number of groups & 37 & 37 & 37 & 37 & 37 \\
\hline
\end{tabular}

This table presents the regression results of the IPO underpricing from 1995 to 2017, by multi-level modelling, when the volume-based market integration is replaced with the mixed measure-Economic Globalization $(E G)$. IPO underpricing is firstly modelled at firm level and then at country level. A random intercept model assumes that the intercept shifts between countries due to the random country effect. Models (1) to (5) present the results including five different country-level institutional variables respectively. Economic Globalization $(E G)$ is the overall economic globalization which takes the average of the de-facto and de-jure economic globalization measures by KOF Swiss Economic Institute. The dependent variable is Underpricing which is the initial return between the first-trading day closing price and the IPO offer price, expressed as a percentage. $V B$ captures the venture-backed status of the IPO firm and equals 1 if the IPO is venture capitalbacked. $B B$ is a dummy variable and equals 1 if the IPO uses book-building as an issuing technique. LSIZE is the offer size of the IPO, expressed in a logarithm. VOLUME, for each country-year companion, is the number of IPOs in a certain year in one country divided by the total number of IPOs throughout the sample period in this country. MRETURN is the 3-month cumulative market return before the IPO, based on the country market index in DataStream. TURNOVER is the stock turnover by value recorded in DataStream which is the value of the shares traded divided by the average market capitalization. UNDERWRITER is the underwriter's reputation which is measured by the IPO market share of this underwriter during the 1995-2017 sample period. Institution represents each of the five country-level institutional variables from Models (1) to (5). IPI is the Investor Protection Index, which measures the level of the legal protection of minority 
investors in one country; it ranges from 0 to 10 with higher values representing better protection. PEI is the Public Enforcement Index, which measures the effectiveness of one country's legal enforcement, i.e. court enforcement; it ranges from 0 to 1 with higher values representing more effective legal enforcement. $R L I$ is the Rule of Law Index, which measures the overall quality of the legal framework; it ranges from 0 to 100 with higher values representing a better legal system. $C P I$ is the Corruption Perception Index, which measures the level of the overall corruption; it ranges from 0 to 100 with 0 representing the most corrupted system. ENGLISH is a dummy variable which equals 1 if the country's legal system originates from English Common Law; 0 otherwise. The variable of interest here is $E G X$ Institution, which is the interaction term between each of these institutional variables and EG. i.e. EGX Institution in Model (1) is equal to $I P I^{*} E G$. $\operatorname{var}($ c.country) is the variance between countries and $\operatorname{var}($ e.ir) is the variance between individual IPOs. The figures below each coefficient are the standard errors. Significance at $10 \%, 5 \%$ and $1 \%$ levels is marked with $*, * *$, and $* * *$ respectively. 
Table 10: Robusntess - Interaction with mean-centred variables

\begin{tabular}{|c|c|c|c|c|c|}
\hline \multirow{2}{*}{$\begin{array}{l}\text { Dependent Variable } \\
\text { Underpricing }\end{array}$} & \multicolumn{5}{|c|}{ Hierarchical Linear Modelling } \\
\hline & $(1)$ & $(2)$ & (3) & (4) & $(5)$ \\
\hline \multirow{3}{*}{$V B$} & Cen_IPI & Cen_PEI & Cen_RLI & Cen_CPI & Cen_ENGLISH \\
\hline & $4.216 * * *$ & $4.201 * * *$ & $4.309 * * *$ & $4.359 * * *$ & $4.407 * * *$ \\
\hline & 1.113 & 1.112 & 1.141 & 1.113 & 1.114 \\
\hline \multirow[t]{2}{*}{$B B$} & $-9.023 * * *$ & $-9.374 * * *$ & $-10.93 * * *$ & $-8.595 * * *$ & $-9.132 * * *$ \\
\hline & 1.407 & 1.438 & 1.587 & 1.425 & 1.414 \\
\hline \multirow[t]{2}{*}{$L S I Z E$} & $-3.860 * * *$ & $-3.732 * * *$ & $-3.754 * * *$ & $-3.726 * * *$ & $-3.734 * * *$ \\
\hline & 0.355 & 0.356 & 0.370 & 0.357 & 0.357 \\
\hline \multirow[t]{2}{*}{ VOLUME } & $-0.440 * * *$ & $-0.460 * * *$ & $-0.421 * * *$ & $-0.465 * * *$ & $-0.450 * * *$ \\
\hline & 0.075 & 0.076 & 0.078 & 0.076 & 0.076 \\
\hline \multirow[t]{2}{*}{ MRETURN } & $0.401 * * *$ & $0.397 * * *$ & $0.406^{* * *}$ & $0.395 * * *$ & $0.397 * * *$ \\
\hline & 0.045 & 0.045 & 0.048 & 0.045 & 0.045 \\
\hline \multirow[t]{2}{*}{ TURNOVER } & $-0.006 * * *$ & $-0.006^{* * *}$ & $-0.005 * * *$ & $-0.006^{* * *}$ & $-0.006^{* * *}$ \\
\hline & 0.001 & 0.001 & 0.001 & 0.001 & 0.001 \\
\hline \multirow[t]{2}{*}{ UNDERWRITER } & $1.776^{* * *}$ & $1.762 * * *$ & $1.778 * * *$ & $1.730 * * *$ & $1.720 * * *$ \\
\hline & 0.219 & 0.219 & 0.224 & 0.219 & 0.219 \\
\hline \multirow[t]{2}{*}{ Cen_MI } & $-0.144 * * *$ & $-0.308 * * *$ & $-0.219 * * *$ & $-0.256 * * *$ & $-0.430 * * *$ \\
\hline & 0.040 & 0.025 & 0.064 & 0.057 & 0.059 \\
\hline \multirow[t]{2}{*}{ Cen_Institution } & $-2.645 * *$ & $-16.36 * * *$ & 5.343 & 0.125 & -3.712 \\
\hline & 1.170 & 3.179 & 22.600 & 0.156 & 3.513 \\
\hline \multirow[t]{2}{*}{$\begin{array}{l}\text { Cen_MIx } \\
\text { Cen_Institution }\end{array}$} & $0.206^{* * *}$ & $0.522 * * *$ & $1.380 * * *$ & $0.010^{* * *}$ & $0.282 * * *$ \\
\hline & 0.032 & 0.096 & 0.487 & 0.003 & 0.089 \\
\hline \multirow[t]{2}{*}{ Constant } & $41.27 * * *$ & $44.52 * * *$ & $37.78 * * *$ & $36.67 * * *$ & $41.92 * * *$ \\
\hline & 2.719 & 3.298 & 3.607 & 3.385 & 3.698 \\
\hline \multirow[t]{2}{*}{$\operatorname{var}($ c.country) } & $102.4 * * *$ & $204.7 * * *$ & $154.5^{* * *}$ & $166.2 * * *$ & $171.7 * * *$ \\
\hline & 32.66 & 60.12 & 45.96 & 47.83 & 49.98 \\
\hline \multirow[t]{2}{*}{$\operatorname{var}(e . i r)$} & $2,136 * * *$ & $2,135 * * *$ & $2,200 * * *$ & $2,142 * * *$ & $2,142 * * *$ \\
\hline & 28.85 & 28.85 & 30.64 & 28.94 & 28.94 \\
\hline Observations & 10,991 & 10,991 & 10,337 & 10,991 & 10,991 \\
\hline Number of groups & 37 & 37 & 37 & 37 & 37 \\
\hline
\end{tabular}

This table presents the regression results of the IPO underpricing from 1995 to 2017, by multi-level modelling, when the market integration $(M I)$ and institutional variables are mean-centred before interacting them. IPO underpricing is firstly modelled at firm level and then at country level. A random intercept model assumes that the intercept shifts between countries due to the random country effect. Models (1) to (5) present the results including five different mean-centred country-level institutional variables respectively. The dependent variable is Underpricing which is the initial return between the first-trading day closing price and the IPO offer price, expressed as a percentage. $V B$ captures the venture-backed status of the IPO firm and equals 1 if the IPO is venture capital-backed. $B B$ is a dummy variable and equals 1 if the IPO uses bookbuilding as an issuing technique. LSIZE is the offer size of the IPO, expressed in logarithm. VOLUME, for each country-year companion, is the number of IPOs in a certain year in one country divided by the total number of IPOs throughout the sample period in this country. MRETURN is the 3-month cumulative market return before the IPO, based on the country market index in DataStream. TURNOVER is the stock turnover by value recorded in DataStream which is the value of the shares traded divided by the average market capitalization. UNDERWRITER is the underwriter's reputation which is measured by the IPO market share of this underwriter during the 1995-2017 sample period. Cen_MI is the mean-centred market integration $(M I)$ which is the R-squared of the regression of a country's daily market performance in a given year on 
global factors, a method developed by Pukthuanthong and Roll (2009). Institution represents each of the five mean-centred country-level institutional variables from Models (1) to (5). Cen IPI is the mean-centred Investor Protection Index, which measures the level of the legal protection of minority investors in one country; it ranges from 0 to 10 with higher values representing better protection. Cen PEI is the mean-centred Public Enforcement Index which measures the effectiveness of one country's legal enforcement, i.e. court enforcement; it ranges from 0 to 1 with higher values representing more effective legal enforcement. Cen_RLI is the mean-centred Rule of Law Index, which measures the overall quality of the legal framework; it ranges from 0 to 100 with higher values representing better legal system. Cen_CPI is the mean-centred Corruption Perception Index, which measures the level of the overall corruption; it ranges from 0 to 100 with 0 representing the most corrupted system Cen ENGLISH is the mean-centred dummy variable which equals 1 if the country's legal system originates from the English Common Law and 0 otherwise. The variable of interest here is Cen_MI $x$ Cen_Institution, which is the interaction term between each of the mean-centred institutional variables and the mean-centred $M I$. i.e. Cen $M I x$ Cen_Institution in Model (1) is equal to Cen_IPI*Cen_MI.var(c.country) is the variance between countries and var(e.ir) is the variance between individual IPOs. The figures below each coefficient are the standard errors. Significance at $10 \%, 5 \%$ and $1 \%$ levels is marked with $* * *$, and $* * *$ respectively. 